\title{
Microglial Receptor for Advanced Glycation End Product-Dependent Signal Pathway Drives $\beta$-Amyloid-Induced Synaptic Depression and Long-Term Depression Impairment in Entorhinal Cortex
}

\author{
Nicola Origlia, ${ }^{1}$ Camilla Bonadonna, ${ }^{1}$ Alfredo Rosellini, ${ }^{1}$ Elena Leznik, ${ }^{2,4}$ Ottavio Arancio, ${ }^{2,4}$ Shirley ShiDu Yan, ${ }^{2,3,4}$ \\ and Luciano Domenici ${ }^{1,5}$ \\ ${ }^{1}$ Neuroscience Institute, Italian National Research Council, Pisa, 56100 Pisa, Italy, Departments of ${ }^{2}$ Pathology and Cell Biology and ${ }^{3}$ Surgery and ${ }^{4}$ Taub \\ Institute for Research on Alzheimer's Disease and Aging Brain, Columbia University, New York, New York 10032, and ${ }^{5}$ Department of Biomedical Science \\ and Technology, University of L'Aquila, 67010 L'Aquila, Italy
}

Overproduction of $\beta$-amyloid $(\mathrm{A} \beta)$ is a pathologic feature of Alzheimer's disease, leading to cognitive impairment. Here, we investigated the impact of cell-specific receptor for advanced glycation end products (RAGE) on A $\beta$-induced entorhinal cortex (EC) synaptic dysfunction. We found both a transient depression of basal synaptic transmission and inhibition of long-term depression (LTD) after the application of A $\beta$ in EC slices. Synaptic depression and LTD impairment induced by A $\beta$ were rescued by functional suppression of RAGE. Remarkably, the rescue was only observed in slices from mice expressing a defective form of RAGE targeted to microglia, but not in slices from mice expressing defective RAGE targeted to neurons. Moreover, we found that the inflammatory cytokine IL- $1 \beta$ (interleukin-1 $\beta$ ) and stress-activated kinases [p38 MAPK (p38 mitogen-activated protein kinase) and JNK (c-Jun N-terminal kinase)] were significantly altered and involved in RAGE signaling pathways depending on RAGE expression in neuron or microglia. These findings suggest a prominent role of microglial RAGE signaling in $\mathrm{A} \beta$-induced EC synaptic dysfunction.

\section{Introduction}

A characteristic feature of Alzheimer's disease (AD) is the presence of $\beta$-amyloid $(\mathrm{A} \beta$ ) deposits to form senile plaques. Animal models of $\mathrm{AD}$ revealed that synaptic and behavioral deficits appear earlier than histopathological signs of neurodegeneration (Chapman et al., 1999; Hsia et al., 1999; Li et al., 1999; Oddo et al., 2003; Ingelsson et al., 2004). This discrepancy has been ascribed to the presence of soluble oligomeric species of $A \beta$ inducing the development of neuronal dysfunction. Synthetic or naturally produced oligomeric $A \beta$ or oligomeric $A \beta$ extracts from cerebral cortex of AD patients are capable of inhibiting hippocampal long-term potentiation (LTP) (Lambert et al., 1998; Chen et al., 2002; Vitolo et al., 2002; Walsh et al., 2002, Wang et al., 2004; Shankar et al., 2008). A few reports have also shown that administration of $\mathrm{A} \beta$ at low micromolar concentrations reduces hippocampal long-term depression (LTD) (Hsieh et al., 2006) [but

Received April 26, 2010; revised June 24, 2010; accepted July 1, 2010.

This work was partially supported by National Institutes of Health Grant P01AG17490 (S.S.D.Y.) and Regione Toscana (Regional Health Research Program 2009) (L.D.). Acknowledgment is made to the donors of the Alzheimer's Disease Research, a program of American Health Assistance Foundation (AHAF) (AHAF Grant A2008-335). We gratefully acknowledge G. Cappagli and C. Orsini for their technical assistance.

Correspondence should be addressed to either of the following: Luciano Domenici, Consiglio Nazionale delle Ricerche Neuroscience Institute, Via G. Moruzzi 1,56100 Pisa, Italy, E-mail: domenici@in.cnr.it; or Shirley ShiDu Yan, Department of Pathology and Surgery, Taub Institute, Columbia University, New York, NY 10032, E-mail: sdy1@columbia.edu.

DOI:10.1523/JNEUROSCI.2127-10.2010

Copyright $\odot 2010$ the authors $\quad 0270-6474 / 10 / 3011414-12 \$ 15.00 / 0$ see Kim et al., 2001; Shankar et al., 2008; Li et al., 2009 (in which $\mathrm{A} \beta$ was shown to facilitate LTD induction); or Wang et al., 2002, 2004; Raymond et al., 2003 (in which A $\beta$ did not affect LTD)]. Furthermore, low micromolar concentrations of $\mathrm{A} \beta$ have been shown to induce synaptic depression by regulating glutamate receptors trafficking (Snyder et al., 2005; Tyszkiewicz and Yan, 2005; Hsieh et al., 2006), whereas lower nanomolar concentrations did not affect basal synaptic transmission (Lambert et al., 1998; Vitolo et al., 2002; Walsh et al., 2002). In agreement with these results, animal models of $\mathrm{AD}$ characterized by progressive accumulation of $A \beta$ showed that LTP disruption occurs before deficits in basal synaptic transmission and LTD (Trinchese et al., 2004; Chang et al., 2006). Thus, progression of synaptic dysfunction by $\mathrm{A} \beta$ is likely to be concentration dependent, possibly corresponding to progressive cognitive decline induced by its accumulation during the course of $\mathrm{AD}$. These studies raise the question of whether the interaction of cell surface receptors with oligomeric $\mathrm{A} \beta$ contributes to aberrant synaptic function.

The receptor for advanced glycation end products (RAGE) functions as a cell surface binding site for $A \beta$ in different cells (neurons, glia, endothelial cells) (Yan et al., 1995; Hofmann et al., 1999; Lue et al., 2001; Schmidt et al., 2001; Deane et al., 2003; Lue et al., 2005; Chen et al., 2007). Furthermore, the introduction of a wild-type RAGE transgene targeted to neurons in the AD-type transgenic mouse model expressing mAPP (mutant human amyloid precursor protein) accelerated $A \beta$-mediated neuronal perturbation (Arancio et al., 2004). As previously demonstrated by 
our groups, specific activation of neuronal RAGE was involved in synaptic dysfunction induced by nanomolar $A \beta$ in the entorhinal cortex (Origlia et al., 2008). In addition, the activation of RAGE in microglia enhances production of proinflammatory mediators, such as interleukin- $1 \beta$ (IL- $1 \beta$ ) and tumor necrosis factor- $\alpha$ (TNF- $\alpha$ ) (Lue et al., 2001) (for review, see Simm et al., 2004; Chen et al., 2007; Fang et al., 2010). This evidence led us to address the question of whether synaptic dysfunction, including progressive synaptic impairment by $\mathrm{A} \beta$ load, depends on cellspecific activation of RAGE, such as neuronal RAGE versus microglial RAGE. In the present study, we investigated the impact of microglial RAGE-dependent signaling on A $\beta$-induced synaptic dysfunction. The study was conducted in the entorhinal cortex (EC), a brain area involved in learning/memory and contributing to cognitive decline at early stages of AD (Braak and Braak, 1991). To achieve our aim, we used new transgenic mice expressing a dominant-negative form of RAGE targeted to microglia (DNMSR) or targeted to neurons (DN-RAGE). We present experimental evidence that synaptic depression and LTD impairment induced by $\mathrm{A} \beta$ are dependent on microglial RAGE. Moreover, we show that the inflammatory cytokine IL- $1 \beta$ and stress-activated kinase [p38 mitogen-activated protein kinase (p38 MAPK) and c-Jun N-terminal kinase (JNK)] phosphorylation is altered and differently involved in RAGE signaling pathways.

\section{Materials and Methods}

Homozygous RAGE-null, transgenic DN-RAGE, and DNMSR mice. Homozygous RAGE-null mice were generated and characterized as described previously (Sakaguchi et al., 2003; Wendt et al., 2003). Homozygous RAGE-null mice were backcrossed for 10 generations into the C57BL/6 background. In addition, we used transgenic mice with signal transduction-deficient mutants of RAGE in which the cytosolic domain of the receptor has been deleted, thereby imparting a dominant-negative RAGE effect, targeted to neurons (DN-RAGE, driven by the plateletderived growth factor-B chain promoter) or to microglia (DNMSR, driven by the macrophage scavenger receptor promoter). The PDGF-B chain promoter has been successfully used to drive expression of transgene targeted to neurons (Sasahara et al., 1991; Mucke et al., 2000; Lustbader et al., 2004; Takuma et al., 2005). Furthermore, transgenic mice expressing neuronal DN-RAGE driven by the PDGF-B chain promoter have been previously characterized, demonstrating localization of DNRAGE in cortical neurons (Arancio et al., 2004). Transgenic mice expressing DN-RAGE in microglia under the macrophage scavenger receptor (MSR) promoter, originally provided by Dr. S. F. Yan (Columbia University, New York, NY), have been used in our previous study (Fang et al., 2010). Male transgenic mice and their littermate controls were used for the in vitro electrophysiology (age range, 2-3 months).

Pharmacologic agents. $\mathrm{A} \beta(1-42)$ and the reversed peptide $\mathrm{A} \beta(42-1)$ were purchased from BioSource. Oligomeric $A \beta(1-42)$ peptide was prepared as described previously and characterized by atomic force microscopy (Yan et al., 2007) and mass spectrometry as reported by Origlia et al. (2009). Aliquots were stored at $20^{\circ} \mathrm{C}$ in DMSO as a $200 \mathrm{~mm}$ stock solution and diluted to the desired final concentration in artificial CSF (ACSF) [containing the following (in $\mathrm{mM}$ ): $119 \mathrm{NaCl}, 2.5 \mathrm{KCl}, 2 \mathrm{CaCl}_{2}, 1.2$ $\mathrm{MgSO}_{4}, 1 \mathrm{NaH}_{2} \mathrm{PO}_{4}, 26.2 \mathrm{NaHCO}_{3}, 11$ glucose], immediately before application (Simmons et al., 1994). 4-(4-Fluorophenyl)-2-(4-metylsulfinylphenyl)-5-(4-pyridyl)-1H-imidazole (SB203580) and anthra(19-cd)pyrazol-6(2H)-one (SP600125) were purchased from Alexis and prepared in DMSO stock solutions. IL- $1 \beta$, interleukin-1 receptor antagonist (IL-1Ra), and TNF- $\alpha$ were purchased from PeproTech. These drugs were also diluted to the desired final concentration in ACSF. Specific antibodies to RAGE have been described in our previous studies (Yan et al., 1996).

Slice preparation. Animals were deeply anesthetized using urethane ( $20 \%$ solution, $1 \mathrm{ml} / 100 \mathrm{~g}$ body weight) via intraperitoneal injection and then decapitated after disappearance of the tail pinch reflex. The brain was rapidly removed and thick horizontal sections $(400 \mu \mathrm{m})$, containing the entorhinal area, were made on a Vibratome. All steps were performed in ice-cold ACSF solution bubbled with $95 \% \mathrm{O}_{2} / 5 \% \mathrm{CO}_{2}$. Before recording, slices were stored for at least $1 \mathrm{~h}$ in a recovery chamber containing oxygenated ACSF solution at room temperature. During electrophysiological recordings, slices were perfused at a rate of $2.5-3 \mathrm{ml} / \mathrm{min}$ with oxygenated ACSF at $33 \pm 1^{\circ} \mathrm{C}$.

Electrophysiological recordings. Extracellular field potentials (FPs) were evoked in layer III in response to electrical stimulation of layer II (Origlia et al., 2008). The amplitude of the FPs was used as a measure of the evoked population excitatory current (Domenici et al., 1995; Pesavento et al., 2002). All FPs had peak latency between 4.5 and 6 ms. Baseline responses were obtained with a stimulation intensity that yielded 50 $60 \%$ of maximal amplitude. FP amplitude was monitored every $20 \mathrm{~s}$ and averaged every three responses by online data acquisition software (Anderson and Collingridge, 2001). After $15 \mathrm{~min}$ of stable baseline recording, low-frequency stimulation (LFS) $(900$ paired pulses at $1 \mathrm{~Hz}$, the interval between paired pulses was $30 \mathrm{~ms}$ ) (Kourrich and Chapman, 2003) was used to induce LTD and its magnitude was measured as the average of FP amplitudes between the 30th and the 40th minute after termination of induction protocol. Values were expressed as mean \pm SEM percentage change relative to their mean baseline amplitude. A $\beta$ peptides were applied by general perfusion for $10 \mathrm{~min}$, unless otherwise stated. The effect of $A \beta$ on basal synaptic transmission was calculated as the average of FPs amplitude recorded during the last 3 min of $A \beta$ perfusion. In experiments using the p38 MAPK inhibitor (SB203580) or JNK inhibitor (SP600125), compounds were continuously perfused over slices (Origlia et al., 2008), starting at least $30 \mathrm{~min}$ before LFS. For patchclamp experiments, $350 \mu \mathrm{m}$ horizontal slices containing EC were cut with a vibratome and maintained as described above. Patch pipettes $(4-6$ $\mathrm{M} \Omega$ ) were pulled from thick-walled borosilicate glass tubing and filled with a solution containing the following: $117.5 \mathrm{~mm}$ Cs-methylsulfonate, $17.5 \mathrm{~mm} \mathrm{CsCl}_{2}, 4 \mathrm{~mm} \mathrm{NaCl}, 0.1 \mathrm{~mm}$ EGTA, $10 \mathrm{~mm}$ HEPES, 5 mm QX$314 \cdot \mathrm{Cl}[\mathrm{N}$-(2,6-dimethylphenylcarbamoylmethyl)triethylammonium chloride] (Tocris), $4 \mathrm{~mm}$ MgATP, $0.3 \mathrm{~mm} \mathrm{Na} \mathrm{N}_{2} \mathrm{GTP}, 10 \mathrm{~mm}$ phosphocreatine-Tris, $\mathrm{pH}$ adjusted to 7.3 with $\mathrm{CsOH}$, osmolarity adjusted to 290 mOsm with sucrose. Currents were recorded with a PC-501A amplifier (Warner Instruments) and filtered at $1 \mathrm{kHz}$ (holding potential, -70 $\mathrm{mV}$ ). The input resistance was determined from the current at the end of a $3 \mathrm{mV}, 10 \mathrm{~ms}$ hyperpolarization voltage step. To eliminate artifacts caused by variation of the seal properties, the access resistance was monitored for constancy throughout all experiments. Synaptic input was evoked by layer II/III stimulation using concentric bipolar electrodes. Ten minutes of stable access resistance were required before beginning measurements of the EPSC amplitude. The amplitude was measured automatically by using the Clampfit program (version 10.2) from Molecular Devices. For the $I-V$ experiments, $3 \mu \mathrm{M}$ bicuculline and $1 \mu \mathrm{M}$ CGP55845[(2S)-3-[[(1S)-1-(3,4-dichlorophenyl)ethyl] amino-2-hydroxypropyl] (phenylmethyl)phosphinic acid hydrochloride] (Tocris), to block $\mathrm{GABA}_{\mathrm{A}}$ and $\mathrm{GABA}_{\mathrm{B}}$ receptors, were added to the bath. To isolate the synaptic currents, membrane currents recorded at each membrane potential in the absence of stimulation were subtracted from the evoked synaptic responses. The AMPA receptor and NMDA receptor currents were calculated as the peak response at $-70 \mathrm{mV}$ and the current measured $50 \mathrm{~ms}$ after the peak at $+50 \mathrm{mV}$, respectively. At the end of all experiments, specific AMPA receptor antagonist NBQX (2,3-dioxo-6-nitro1,2,3,4-tetrahydrobenzo[f] quinoxaline-7-sulfonamide) $\left(\begin{array}{lll}10 & \mu \mathrm{M}\end{array}\right)$ and NMDA receptor antagonist AP5 $(50 \mu \mathrm{M})$ were added to confirm the correct isolation of AMPA and NMDA currents. For miniature EPSCs (mEPSCs) in the intracellular solution, Cs-methylsulfonate and $\mathrm{CsCl}_{2}$ were substituted with K-gluconate and $\mathrm{KCl}$. mEPSCs were recorded at $-60 \mathrm{mV}$ in the presence of $1 \mu \mathrm{M}$ tetrodotoxin and $3 \mu \mathrm{M}$ bicuculline and analyzed using Mini Analysis Program (Synaptosoft) considering currents $>5 \mathrm{pA}$.

ELISAs. Quantification of phosphorylated [pTpY180/182]p38 MAPK or phosphorylated [pTpY183/185]JNK were detected in protein extracts from slices collected after electrophysiology using two different ELISA kits (BioSource); levels of phosphorylated forms were normalized with respect to the total $\mathrm{p} 38$ MAPK and total JNK protein content that was 
assessed using two ELISA kits purchased from the same company (BioSource). Quantification of IL- $1 \beta$ and TNF- $\alpha$ was performed using ELISA kits purchased from Bender Medsystem. After electrophysiology, slices were collected, immediately frozen at $-80^{\circ} \mathrm{C}$, and subsequently lysed in cell extraction buffer (10 mm Tris, pH 7.4, $100 \mathrm{~mm} \mathrm{NaCl}, 1$ mm EDTA, 1 mm EGTA, $1 \mathrm{~mm} \mathrm{NaF}, 20 \mathrm{~mm} \mathrm{Na}_{4} \mathrm{P}_{2} \mathrm{O}_{7}, 2 \mathrm{~mm} \mathrm{Na}_{3} \mathrm{VO}_{4}, 1 \%$ Triton X-100, $10 \%$ glycerol, $0.1 \%$ SDS, $0.5 \%$ deoxycholate, and 1 mM PMSF; SigmaAldrich protease mixture inhibitor). The extract was then centrifuged $\left(13,000 \mathrm{rpm}, 10 \mathrm{~min}\right.$ at $\left.4^{\circ} \mathrm{C}\right)$ to obtain a clear lysate that was used for the assay.

Statistical analysis. All data are reported as mean \pm SEM. Statistical comparisons between experimental groups or between FP amplitudes measured during baseline and after the induction protocol were performed by applying two-way repeated-measures ANOVA with pairwise multiple-comparison procedures (Holm-Sidak method). Comparisons between different groups in ELISA experiments were performed using one-way ANOVA. Differences were considered significant when $p<0.05$.

\section{Results}

\section{Micromolar A $\beta$ causes synaptic depression and LTD impairment in entorhinal cortex}

Several lines of evidence show a progressive impairment of synaptic function with increasing $A \beta$ concentrations. In particular, synthetic oligomeric $A \beta(1-42)$ in the nanomolar range was shown to inhibit LTP leaving unaffected synaptic transmission (for EC, see Origlia et al., 2008; for hippocampus, see Vitolo et al., 2002). Higher micromolar concentrations caused synaptic depression and LTD reduction in hippocampus (Snyder et al., 2005; Hsieh et al., 2006; Parameshwaran et al., 2007). These studies prompted us to investigate the effect of synthetic oligomeric A $\beta$ (1-42) on basal synaptic transmission and LFS-induced LTD in EC. This $\mathrm{A} \beta$ preparation was previously characterized (Origlia et al., 2009) and showed the presence of monomers, dimers, and trimers (Yan et al., 2007). We focused our studies on the EC, an area of the brain connected both to the hippocampus and associative cortical areas, and crucially involved in cognitive functions (Witter et al., 1989). In addition, this brain area is affected at an early stage of AD (Braak and Braak, 1991). In horizontal slices of EC, we recorded FPs from superficial cortical layer II/III after stimulation of layer II, as described by Origlia et al. (2008). Bath application of $1 \mu \mathrm{M} \mathrm{A} \beta$ for 10 min caused a significant decrease of FP amplitude with respect to vehicle and $\mathrm{A} \beta(42-1)$-treated slices $(83 \pm 2 \%, n=11$, vs $103 \pm 2 \%, n=7$, and $101 \pm 2 \%, n=6 ; p<$ $0.05)$ (Fig. 1A). A $\beta$-induced synaptic depression was transient and FP amplitude returned to baseline values after washout (Fig. $1 A)$. We also investigated whether $1 \mu \mathrm{M} \mathrm{A} \beta$ was able to affect LTD, a long-term form of synaptic plasticity that can be reliably induced in EC through a LFS protocol (900 paired pulses at $1 \mathrm{~Hz}$, $30 \mathrm{~ms}$ interstimulus interval) (Origlia et al., 2008). LFS induced stable LTD (Fig. $1 B$ ) in vehicle-treated slices (mean FP amplitude was $80 \pm 6 \% ; n=11 ; p<0.05$ vs baseline). As previously demonstrated (Kourrich and Chapman, 2003), LTD was NMDA dependent because it was blocked by the NMDA receptor blocker AP5 $(50 \mu \mathrm{M})$ (Fig. $1 B$ ) (mean FP amplitude was $99 \pm 3 \%$; $p=$ 0.38 vs baseline). This form of LTD was not saturated after the first LFS and additional depression was induced using a second LFS stimulation (supplemental Fig. S1 A, available at www. jneurosci.org as supplemental material). Bath perfusion of $\mathrm{A} \beta$ ( 1 $\mu \mathrm{M})$ starting before LFS stimulation inhibited LTD expression (Fig. 1C), when applied for a short period (mean amplitude 40 min after LFS was $78 \pm 7 \% ; n=7 ; p>0.05$ vs FP amplitude during $\mathrm{A} \beta$ perfusion). To rule out the possibility that $\mathrm{A} \beta$ effect was already vanished by the time of LFS application, we pro- longed the period of $\mathrm{A} \beta$ perfusion throughout the LFS stimulation $(40 \mathrm{~min}$ ). Also in this case (Fig. $1 \mathrm{D})$, LTD was blocked (mean amplitude $40 \mathrm{~min}$ after LFS was $84 \pm 5 \% ; p>0.05$ vs $81 \pm 4 \%$ during $\mathrm{A} \beta$ perfusion; $n=8$ ). Interestingly, $\mathrm{A} \beta$ effect was reversible and LTD normally expressed when LFS was applied after A $\beta$ washout (Fig. $1 E$ ) (mean LTD was $78 \pm 7 \% ; n=8$; $p<0.05$ vs baseline). Furthermore, $A \beta$-induced depression was not occluded by LFS as shown in Figure $1 F$ (mean amplitude was $66 \pm$ $5 \%$ during $A \beta$ perfusion; $p<0.05$ vs $78 \pm 5 \%$ after LFS; $n=10$ ). Together, these results suggest that micromolar $A \beta$ induces transient synaptic depression and inhibition of LFS-LTD.

Since A $\beta$ synaptic depression has been linked to reduction of AMPA or NMDA currents (Snyder et al., 2005; Hsieh et al., 2006; Parameshwaran et al., 2007), we next sought to determine the effect of 10 min $1 \mu \mathrm{M} \mathrm{A} \beta(1-42)$ on AMPA- and NMDA-receptor mediated currents in layer II/III pyramidal neurons of EC. First, we recorded spontaneous mEPSCs in the presence of tetrodotoxin (TTX) and bicuculline. The mean amplitude of mEPSCs (Fig. 2B), but not the frequency (Fig. 2C), was affected by the treatment with $1 \mu \mathrm{M} \mathrm{A} \beta$ for 10 min (mean amplitude was $9 \pm 0.7$ $\mathrm{pA}, n=7$, vs $14.4 \pm 0.6 \mathrm{pA}$ in vehicle-treated cells, $n=13$; $p<$ 0.05 ). After washing out $\mathrm{A} \beta$ (Fig. $2 A, B$ ), the amplitude of mEPSCs returned to control values. We then assessed AMPA and NMDA EPSCs and their relative current-voltage $(I-V)$ relationships before and after perfusion of the slices with $1 \mu \mathrm{M} \mathrm{A} \beta$ for 10 min. A $\beta$ caused a significant reduction of AMPA-mediated EPSC peak amplitude (Fig. 2D,E) (mean amplitude recorded at -70 $\mathrm{mV}$ was $77 \pm 1 \%$ of baseline; $n=10 ; p<0.05$ vs $99 \pm 2 \%$ in vehicle-treated slices and $96 \pm 3 \%$ during washout), but did not significantly affect NMDA currents (Fig. 2D,F). Our results are in agreement with previous findings (Hsieh et al., 2006; Shemer et al., 2006; Parameshwaran et al., 2007), suggesting an involvement of AMPA receptor-mediated current in $\mathrm{A} \beta$-dependent alteration of synaptic transmission (see also supplemental Fig. S1 B, C, available at www.jneurosci.org as supplemental material, showing that $A \beta$ induced depression is not affected by perfusion with the NMDA receptor blocker AP5). Thus, $1 \mu \mathrm{M} A \beta$ not only impairs LFS-LTD in EC but also induces a reduction in FP amplitude associated with reduction of spontaneous AMPA mEPSC amplitude and evoked AMPA EPSC amplitude.

\section{Microglial RAGE contributes to A $\beta$-dependent synaptic depression and LTD impairment}

RAGE is a key receptor, mediating $\mathrm{A} \beta$-induced synaptic plasticity impairment in the hippocampus (Arancio et al., 2004) and in cortical areas (Origlia et al., 2008, 2009). In particular, functionless RAGE in neurons was able to abolish $200 \mathrm{~nm} \mathrm{~A} \beta$ inhibition of LTP (Origlia et al., 2008). To test whether RAGE was involved in $1 \mu \mathrm{M} \mathrm{A} \beta$-induced depression and LTD inhibition, we first examined the effect of 10 min application of $\mathrm{A} \beta(1-42)$ in EC slices from RAGE-null mice and in slices from WT mice pretreated with anti-RAGE IgG $(2.5 \mu \mathrm{g} / \mathrm{ml}$ in ACSF). As previously reported, RAGE deficiency does not affect basal synaptic transmission and LTD expression in EC slices (Origlia et al., 2008). As shown in Figure $3 A$, blockade of RAGE by either knocking out RAGE gene or neutralizing anti-RAGE IgG was able to prevent $\mathrm{A} \beta$-dependent synaptic depression. The mean FP amplitude in RAGE-null mice ( $97 \pm 2 \% ; n=5)$ and anti-RAGE IgG (99 $\pm 2 \%$; $n=5$ )-treated slices did not significantly change during $\mathrm{A} \beta$ perfusion and was significantly different from WT slices treated with A $\beta$ alone $(83 \pm 2 \% ; n=11 ; p<0.05)$. These results confirmed that RAGE contributes to amyloid-induced synaptic dysfunction. RAGE is expressed in neurons as well as in other non- 


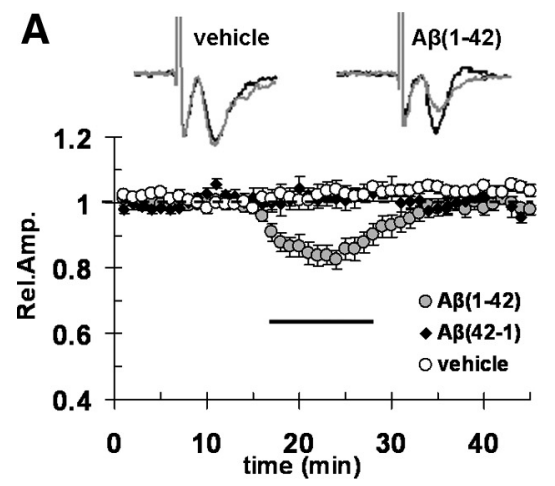

C

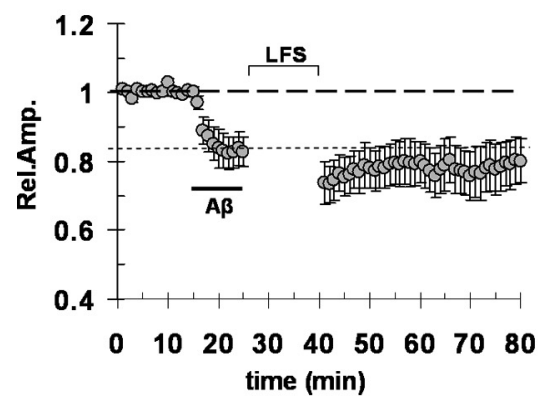

E

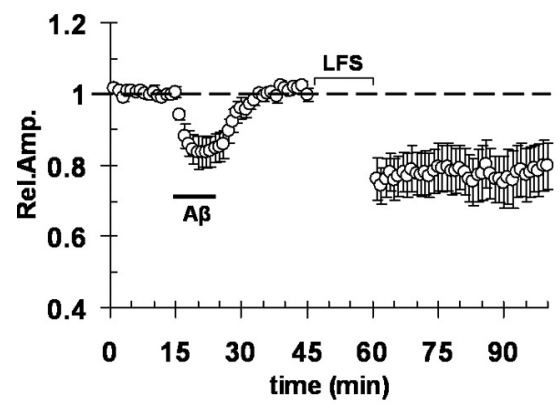

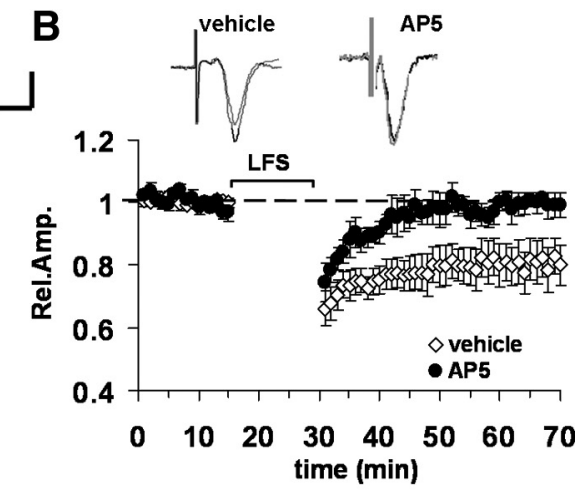

D

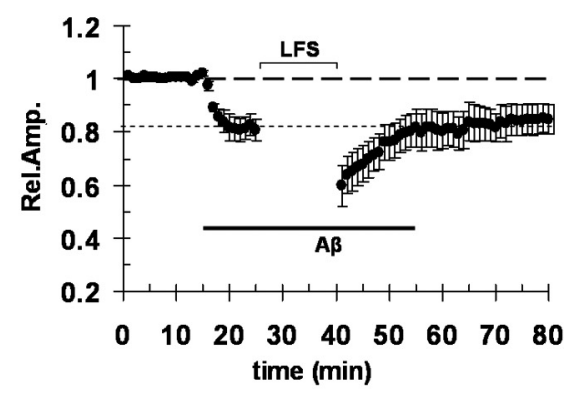

F

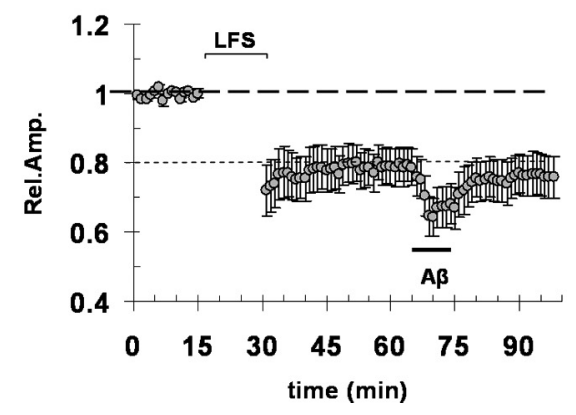

Figure 1. $A \beta(1 \mu \mathrm{M})$ causes synaptic depression and LTD impairment in entorhinal cortex. $A$, Acute application of $1 \mu \mathrm{M}$ $A \beta(1-42)$ for 10 min (corresponding to dark bar) induced a depression of FP amplitude (gray circles), whereas no change in FP amplitude was observed in vehicle-treated slices (white circle) and in control slices treated with the reverse sequence peptide $\mathrm{A} \beta(42-1)$ at $1 \mu \mathrm{m}$ for $10 \mathrm{~min}$ (black circles); the insets represent typical traces of FPs recordings before (thick line) and during $A \beta$ perfusion. B, LFS (900 paired pulses at $1 \mathrm{~Hz}, 30$ ms interstimulus interval) was able to induce LTD in control vehicle-treated slices, but failed to do so in slices treated with $50 \mu \mathrm{M} \mathrm{AP5}$; the insets represent typical traces of FPs recordings before and after LFS in vehicle- or AP5-treated slices. C, Bath perfusion with $1 \mu \mathrm{m} A \beta$ before LFS stimulation induced a significant depression of FP amplitude that inhibits LFS-induced LTD; indeed, the magnitude of FPs after LFS was unchanged. $D$, LTD was blocked by prolonged perfusion (40 min) with $A \beta(1 \mu \mathrm{M})$ and simultaneous LFS application. $\boldsymbol{E}$, Acute application for 10 min (dark bar) of $A \beta$ (1 $\mu \mathrm{M})$ induced a depression of FP amplitude that recovers to the baseline after washout; LTD was normally expressed when LFS was applied after $A \beta$ washout. $\boldsymbol{F}, A \beta$ (10 min perfusion)-induced depression was not occluded by LFS. Calibration: $\boldsymbol{A}, \boldsymbol{B}$, horizontal, 5 $\mathrm{ms}$; vertical, $0.5 \mathrm{mV}$. Error bars indicate SEM.

neuronal cells (glial cells, endothelial cells) (Schmidt et al., 2001; Lue et al., 2005, Chen et al., 2007). Thus, we analyzed the contribution of RAGE expressed in different cell types, such as in neurons and microglia, to $A \beta$-induced synaptic depression. To investigate this issue, we used EC slices obtained from mice overexpressing a dominant-negative form of RAGE targeted to neurons (DN-RAGE) and to microglia (DNMSR). Remarkably, deficiency of RAGE in neurons (DN-RAGE) (Fig. 3B) was not sufficient to prevent $\mathrm{A} \beta$ synaptic depression $(76 \pm 5 \%$; $n=6 ; p<$ 0.05 vs vehicle-treated slices); in contrast, $\mathrm{A} \beta$ failed to induce synaptic depression in DNMSR slices ( $98 \pm 1 \%$; $n=6 ; p>0.05$ vs vehicle-treated slices). In addition, both a complete deficiency of RAGE (RAGE-null slices or anti-RAGE IgG-treated slices) and a selective inactivation of RAGE in microglia (DNMSR) were able to prevent $A \beta$-dependent LTD inhibition (Fig. 3C-E) using bath application of $1 \mu \mathrm{M} \mathrm{A} \beta$ for $10 \mathrm{~min}$; similar results were obtained with prolonged application of $1 \mu \mathrm{M} \mathrm{A} \beta$ for $40 \mathrm{~min}$ (anti-RAGE IgG, $n=4$; DNMSR, $n=5$ ) (data not shown). After $1 \mu \mathrm{M} \mathrm{A} \beta$ treatment, LTD induced by LFS in RAGE-null (74 $\pm 8 \% ; n=5$ ), antiRAGE IgG $(73 \pm 9 \% ; n=5)$, and DNMSR slices $(80 \pm 7 \% ; n=7)$ was comparable with controls $(p>0.05$ vs $80 \pm 6 \%$; $n=$ 11 in vehicle-treated slices) (Fig. 1) or to DNMSR slices without $\mathrm{A} \beta$ (supplemental Fig. S2 $A$, available at www.jneurosci.org as supplemental material). In contrast, LTD inhibition was observed in DNRAGE slices treated with $\mathrm{A} \beta$ (Fig. $3 F$ ). Thus, microglial RAGE activation by $1 \mu \mathrm{M}$ $\mathrm{A} \beta$ is relevant to induce synaptic depression and LTD impairment.

\section{A $\boldsymbol{\beta}$-dependent synaptic depression and LTD inhibition is mimicked by IL-1 $\beta$ and prevented by IL- $1 \beta$ receptor antagonist}

So far, our data showed that micromolar $\mathrm{A} \beta(1-42)$ activates RAGE in microglia leading to synaptic dysfunction. The next step was to investigate the factors and mechanisms linking microglial activation by $A \beta /$ RAGE signaling to synaptic dysfunction. Microglial RAGE has been implicated in the development of inflammatory response and cellular dysfunction (Lue et al., 2001; Bianchi et al., 2010). Cytokines, in particular IL- $1 \beta$ and TNF- $\alpha$, released by microglial cells, are key molecules that are capable of modulating synaptic function and plasticity (Coogan et al., 1999; Ikegaya et al., 2003; Kelly et al., 2003; Pickering et al., 2005). To test the possible involvement of cytokines, we first tried to mimic $\mathrm{A} \beta$-dependent synaptic depression by exogenously applying IL-1 $\beta(1 \mathrm{ng} / \mathrm{ml})$ and TNF- $\alpha(5 \mathrm{ng} / \mathrm{ml})$ on slices for $10 \mathrm{~min}$. We found (Fig. $4 A$ ) that IL- $1 \beta$, but not TNF- $\alpha$, was able to significantly depress basal synaptic transmission ( $83 \pm 5 \%, n=5, p<0.05$ vs baseline, and $98 \pm 4 \%, n=5$, $p>0.05$ vs baseline, respectively). Differently to what observed in $\mathrm{A} \beta$-treated slices, IL- $1 \beta$-induced depression was persistent and FP amplitude did not return to baseline values after the washout (Fig. 4A). This result is consistent with the previous finding in the hippocampus, showing a similar degree of persistent depression after bath application of IL- $1 \beta$; induction and maintenance phases of synaptic depression are differently modulated by GABA receptor activation with a GABA receptor-independent acute phase and a GABA receptor-dependent, maintenance phase sensitive to $\mathrm{GABA}_{\mathrm{A}}$ receptor block (Ikegaya et al., 2003). To investigate whether the different kinetics of synaptic depression 
A
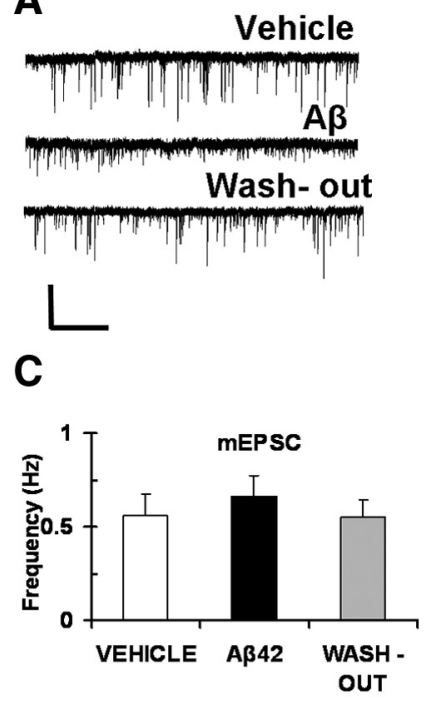

E
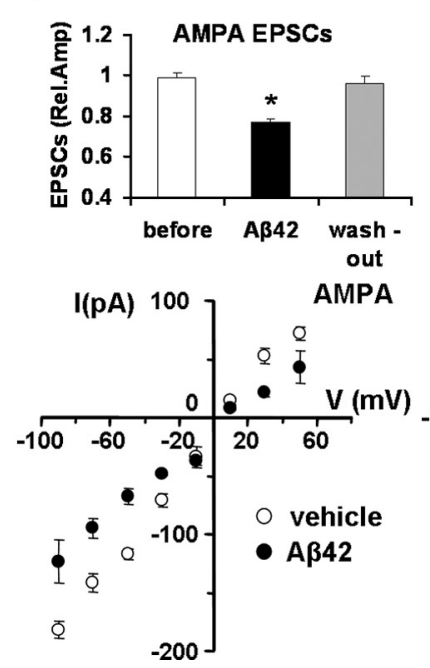

B

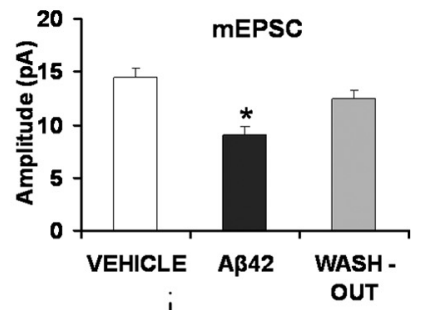

D

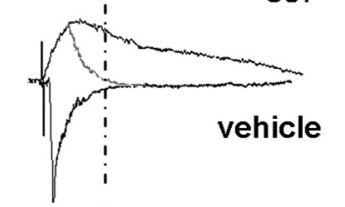

$A \beta$

$\mathbf{F}$
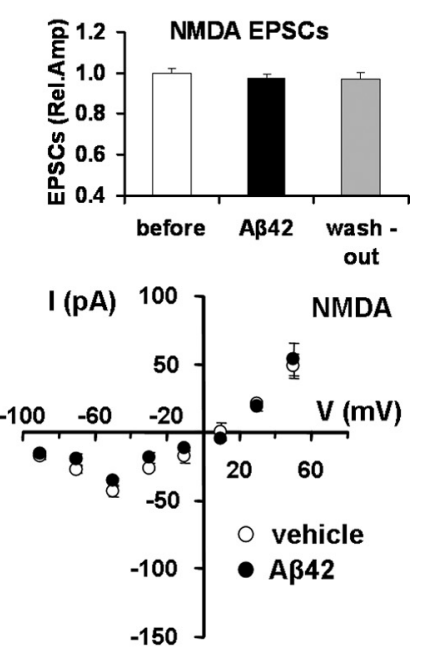

Figure 2. $\quad A \beta(1 \mu \mathrm{M})$ affects $m E P S C$ amplitude and depresses AMPA-mediated synaptic transmission. $A$, mEPSCs recorded in the presence of TTX $(1 \mu \mathrm{m})$ and bicuculline $(3 \mu \mathrm{M})$; examples of traces recorded before, during, and after perfusion with $1 \mu \mathrm{m} A \beta(1-42)$. Calibration: horizontal, 10 s; vertical, 20 pA. $\boldsymbol{B}$, The plot represents average mEPSC amplitude recorded in control condition (vehicle), during 10 min perfusion with $1 \mu \mathrm{M} \mathrm{A} \beta$, and after $A \beta$ washout. $m E P S C$ amplitude was significantly decreased $\left({ }^{*} p<0.05\right)$ during $A \beta$ perfusion; after washing out $A \beta$, the amplitude of mEPSCs returned to control values. $C$, Ten minute perfusion with $1 \mu \mathrm{m} A \beta$ had no effect on the frequency of mEPSC; plot represents average frequency of $m E P S C s$ recorded in control condition (vehicle), during 1 $\mu \mathrm{m} A \beta$ perfusion, and after $A \beta$ washout. $\boldsymbol{D}$, Traces represent examples of evoked EPSCs that were recorded at -70 and $+50 \mathrm{mV}$, respectively, in control (vehicle) and after $1 \mu \mathrm{M}$ $A \beta$ perfusion. The amplitude of AMPA EPSC component was measured at $-70 \mathrm{mV}$, whereas NMDA EPSC component was calculated at $+50 \mathrm{mV}, 50 \mathrm{~ms}$ after the AMPA peak (see dashed lines). The gray traces represent recordings at $+50 \mathrm{mV}$, where the AMPA component was isolated using AP5 (50 $\mu \mathrm{m})$. Calibration: horizontal, $50 \mathrm{~ms}$; vertical, $50 \mathrm{pA}$. $\boldsymbol{E}$, Perfusion with $1 \mu \mathrm{M} \mathrm{A} \beta$ caused a significant reduction of AMPA-mediated EPSC peak amplitude; in the top panel, the plot represents averaged relative amplitude of AMPA EPSCs recorded at $-70 \mathrm{mV}$ in control condition (vehicle), during $10 \mathrm{~min}$ of $1 \mu \mathrm{M} \mathrm{A} \beta$ perfusion, and after $A \beta$ washout $\left({ }^{*} p<0.01\right)$. In the bottom panel, a complete $I-V$ curve is reported for AMPA EPSCs recorded in control (vehicle), during $A \beta$ perfusion. $F, A \beta$ did not significantly affect NMDA currents; in the top panel, the plot represents averaged relative amplitude of NMDA EPSCs recorded at $+50 \mathrm{mV}$ in control condition (vehicle), during 10 min of $1 \mu \mathrm{MA} \beta$ perfusion, and after $A \beta$ washout $\left({ }^{*} p<0.01\right)$. In the bottom panel, a complete $I-V$ curve is reported for NMDA EPSCs recorded in control (vehicle) conditions and under $A \beta$ perfusion. Error bars indicate SEM.

between $\mathrm{A} \beta$ and IL- $1 \beta$ might reflect a different sensitivity to GABAergic drugs, we used the $\mathrm{GABA}_{\mathrm{A}}$ receptor antagonist bicuculline. $A \beta$ synaptic depression was not modified by bicuculline (supplemental Fig. S2 B, available at www.jneurosci.org as supplemental material). Moreover, IL- $1 \beta$ perfusion before LFS inhibited LTD in EC slices (Fig. 4B), similarly to what was observed with $1 \mu \mathrm{M} \mathrm{A} \beta$ and according to what has been previously shown in the hippocampus (Ikegaya et al., 2003). In contrast, LTD was normally expressed in slices treated with TNF- $\alpha$ (supplemental Fig. S2C, available at www.jneurosci.org as supplemental material). To determine a direct effect of IL- $1 \beta$ on $A \beta$-induced synaptic depression, we perfused the slices with $1 \mu \mathrm{M} \mathrm{A} \beta(1-42)$ in the presence of IL-1Ra, the interleukin-1 receptor antagonist. As reported in Figure $4 C$, when slices were treated with IL-1Ra $(20$ $\mathrm{ng} / \mathrm{ml}$ ), $1 \mu \mathrm{M} \mathrm{A} \beta$ failed to induce synaptic depression (mean FP amplitude was $98 \pm 3 \% ; n=6 ; p>0.05$ vs baseline). In addition, treating the slices with IL- 1 Ra prevented LTD inhibition after $\mathrm{A} \beta$ exposure; the mean LTD under this condition $(74 \pm 4 \% ; n=5)$ (Fig. $4 D$ ) was comparable with LTD recorded in vehicle-treated slices (Fig. $1 B$ ). Thus, IL- $1 \beta$ contributes to $1 \mu \mathrm{M} \mathrm{A} \beta$ effects on synaptic function. We next investigated whether $A \beta /$ RAGE interaction induces an increase of IL- $1 \beta$ level in EC slices. Using an ELISA (Fig. $4 E$ ), we found that IL- $1 \beta$ level was significantly increased in EC slices exposed to $1 \mu \mathrm{M} \mathrm{A} \beta$ for $10 \min (39.7 \pm 0.7$ $\mathrm{pg} / \mathrm{ml}$ vs $17.4 \pm 1.4 \mathrm{pg} / \mathrm{ml}$ in control slices; $n=6$; $p<0.05$ ). Deficiency of RAGE signaling in microglia (DNMSR slices) and RAGE blockade by anti-RAGE IgG were not able to modify basal IL- $1 \beta$ levels ( $16.8 \pm 4.6$ and $19.2 \pm 2.8 \mathrm{pg} / \mathrm{ml}$, respectively; $n=6$; $p>0.05$ vs control). More importantly, RAGE blockade by antiRAGE IgG and deficiency of RAGE signaling in microglia completely prevented $1 \mu \mathrm{M} \mathrm{A} \beta$ effect, maintaining IL-1 $\beta$ levels comparable with basal values $(21.7 \pm 2.5$ and $19.4 \pm 1.8 \mathrm{pg} / \mathrm{ml}$, respectively; $n=6 ; p>0.05$ vs control, $p<0.05$ vs A $\beta$ alone). We also measured TNF- $\alpha$ level in the same experimental condition without finding any significant increase after $\mathrm{A} \beta$ treatment (supplemental Fig. S2D, available at www.jneurosci.org as supplemental material). Interestingly, low concentrations of $A \beta$ ( 250 and $500 \mathrm{~nm}$ ) (Fig. $4 F$ ) did not produce any increase in IL-1 $\beta$ with respect to vehicle-treated slices. Moreover, a higher concentration of $\mathrm{A} \beta(2 \mu \mathrm{M})$ was unable to induce additional increase of IL- $1 \beta$ levels with respect to results obtained with $1 \mu \mathrm{M} \mathrm{A} \beta$ (Fig. $4 F)$. Thus, $A \beta$ mediated the induction of IL- $1 \beta$ in EC slices at concentration and application times comparable with those used to induce synaptic depression and LTD inhibition.

\section{A $\beta$-induced synaptic depression and LTD inhibition is prevented by inhibition of JNK and p38 MAPK}

Stress-related protein kinases, such as JNK and p38 MAPK, are activated in several pathologic processes, including $\mathrm{AD}$ neurodegeneration and $\mathrm{A} \beta$ cytotoxicity (Pei et al., 2001; Troy et al., 2001; Zhu et al., 2005). It is noteworthy that both JNK and p38 MAPK inhibition prevented A $\beta$-induced LTP impairment in hippocampal (Wang et al., 2004) and EC slices (Origlia et al., 2008). In particular, we demonstrated that $200 \mathrm{nM} \mathrm{A} \beta(1-42)$ interacting with neuronal RAGE induced impairment of LTP through activation of p38 MAPK signaling cascades (Origlia et al., 2008). To determine whether micromolar $\mathrm{A} \beta(1 \mu \mathrm{M})$ affects synaptic function through the stress-activated signaling cascades, we used different inhibitors of kinases. In particular, we used a JNK inhibitor (SP600125) and a p38 MAPK inhibitor (SB203580) to prevent $\mathrm{A} \beta$-induced synaptic depression (Lali et al., 2000; Bennett et al., 2001). Perfusion with either compound did not induce significant change in extracellular FP amplitude during baseline record- 

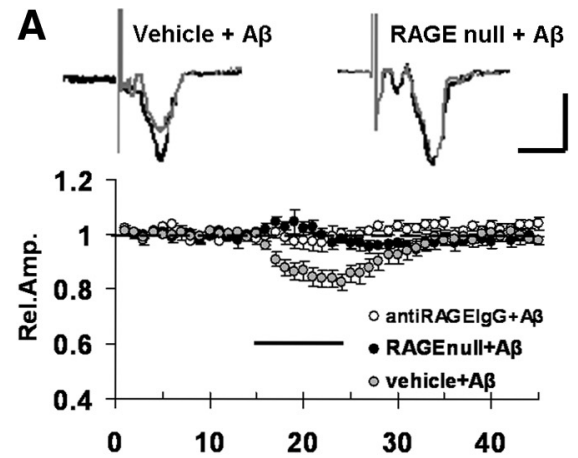

C

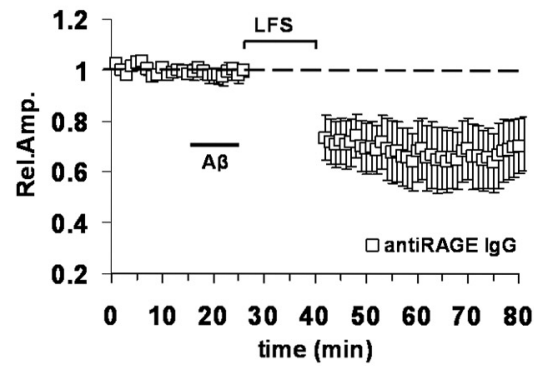

E

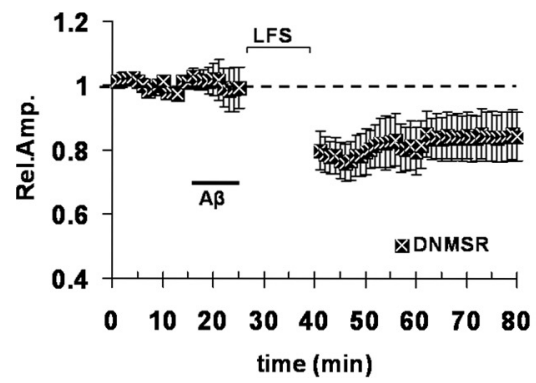

B
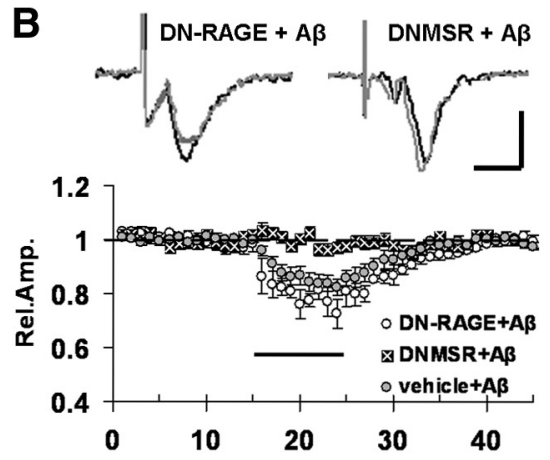

D

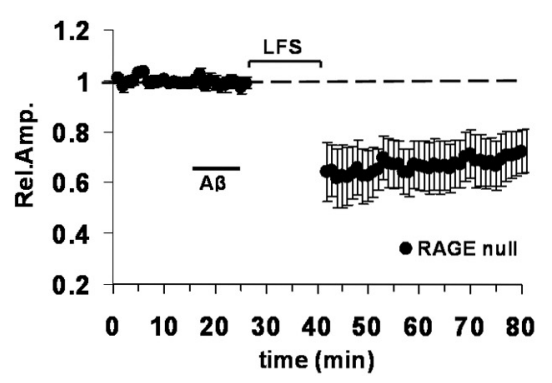

$\mathbf{F}$

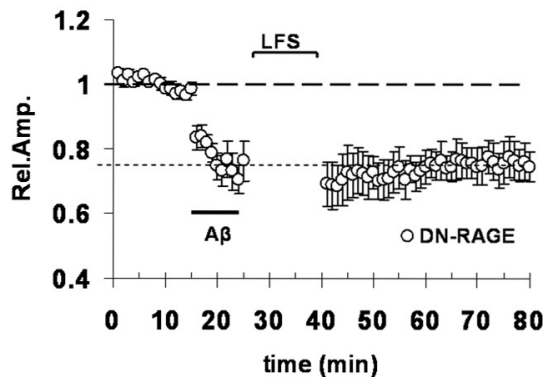

Figure 3. Microglial RAGE contributes to $A \beta$-induced synaptic depression and LTD impairment. $A$, Blockade of RAGE by either knocking out RAGE gene or with neutralizing anti-RAGE IgG was able to prevent $A \beta$ depression; FP amplitude in RAGE-null (black circles) and anti-RAGE IgG (white circles)-treated slices did not significantly change during $10 \min 1 \mu \mathrm{m} A \beta(1-42)$ perfusion (dark bar) and was significantly different from FP amplitude in WT slices treated with A $\beta$ alone (gray circles). $\boldsymbol{B}$, RAGE-deficient signaling in neurons (DN-RAGE, white circles) was not sufficient to prevent $1 \mu \mathrm{m} A \beta$-induced synaptic depression; in contrast, $A \beta$ failed to induce synaptic depression in DNMSR slices characterized by RAGE signaling deficiency in microglia (black squares). After $1 \mu \mathrm{mA} \beta$ treatment (dark bar), LTD was not impaired and normally expressed in anti-RAGE IgG-treated (C, white squares), RAGE-null ( $\boldsymbol{D}$, black circles), and DNMSR slices (E, dark squares). $\boldsymbol{F}$, In contrast, LTD impairment was observed in DN-RAGE slices treated with A $\beta$. The insets in $\boldsymbol{A}$ and $\boldsymbol{B}$ represent typical traces of FPs recordings before (dark line) and during (gray line) $A \beta$ perfusion. Calibration: horizontal, $5 \mathrm{~ms}$; vertical, $0.5 \mathrm{mV}$. Error bars indicate SEM.

ings in EC slices in agreement with what has been previously reported (Origlia et al., 2008). When slices were continuously perfused with $1 \mu \mathrm{M}$ SB203580 or $20 \mu \mathrm{M}$ SP600125 (Fig. 5A), 10 min application of $1 \mu \mathrm{M} \mathrm{A} \beta(1-42)$ was unable to cause synaptic depression $(100 \pm 3 \%, n=6$, and $102 \pm 4 \%, n=6$, respectively; $p>0.05$ vs baseline; $p<0.05$ vs $83 \pm 2 \% ; n=11$ in slices treated with $A \beta$ alone). This suggests that synaptic depression elicited by $\mathrm{A} \beta$ is dependent on the activation of either JNK or p38 MAPK. However, these two kinases are differently involved in EC LTD expression (Fig. 5B), for instance, LTD was completely abolished by p38 MAPK inhibition using SB203580 (104 $\pm 5 \% ; n=6 ; p>$ 0.05 vs baseline), whereas LTD was unaffected when slices were perfused with the JNK inhibitor (SP600125; $74 \pm 8 \% ; n=7 ; p<$ 0.05 vs baseline; $p>0.05$ vs control) (Fig. $1 B$ ). This result indicates that p38 MAPK, but not JNK, is required for LTD expres- sion in the EC, which is in agreement with previous studies showing a role for p38MAK activation in both metabotropic glutamate receptor (mGluR)-dependent and NMDA-dependent LTD in the hippocampus (Bolshakov et al., 2000; Rush et al., 2002; Zhu et al., 2002; Huang et al., 2004; Hsieh et al., 2006) and neocortex (Xiong et al., 2006). Next, we examined the effect of JNK that is not involved in physiological mechanisms underlying LFS-LTD with the aim of preventing $\mathrm{A} \beta$-dependent LTD inhibition. Using SP600125, we rescued LTD elicited by LFS in EC slices exposed to $1 \mu \mathrm{M} \mathrm{A} \beta$ (Fig. 5C) (mean LTD was $73 \pm 9 \% ; n=6$; $p<$ 0.05 vs baseline). Our results suggest that p38 MAPK and JNK are important key events in $\mathrm{A} \beta$-dependent synaptic depression and LTD impairment.

\section{A $\beta$ increases p38 MAPK and JNK phosphorylation in cortical slices} To further investigate the effect of RAGEdependent activation of p38 MAPK and JNK on $\mathrm{A} \beta$-mediated neuronal dysfunction, we measured the levels of phosphorylated p38 MAPK and phosphorylated JNK in EC slices that were collected after the end of electrophysiological experiments. When slices were analyzed after 10 min perfusion with $1 \mu \mathrm{M} \mathrm{A} \beta(1-42)$, we found an increase of p38 MAPK phosphorylation (Fig. 6A). Tissue level of phospho-p38 MAPK in the presence of $\mathrm{A} \beta$ was significantly higher than that in control vehicle-treated slices $(21.6 \pm 7.9$ vs $5.2 \pm 1.52 \mathrm{U} / \mathrm{ng} ; n=6$; $p<0.05)$. Selective deficiency of RAGE signaling in microglia (DNMSR) or complete inactivation of RAGE (anti-RAGE IgG) did not modify the basal level of phospho-p38 MAPK $(3.9 \pm 0.2$ and $5.5 \pm 2 \mathrm{U} / \mathrm{ng}$, respectively; $n=6 ; p>0.05$ vs control vehicle). However, slices either from DNMSR mice or WT mice treated with anti-RAGE IgG displayed complete suppression of phospho-p38 MAPK in the presence of $\mathrm{A} \beta(3 \pm 1.3$ and $2.4 \pm 0.7 \mathrm{U} / \mathrm{ng}$ in DNMSR and anti-RAGE IgG-treated slices, respectively; $n=6 ; p<0.05$ vs slices treated with $\mathrm{A} \beta$ alone). These data indicate the contribution of microglial RAGE signaling to the $A \beta$-involved activation of p38 signal pathway. To further examine the effect of IL- $1 \beta$ on $\mathrm{A} \beta$-induced activation of $\mathrm{p} 38 \mathrm{MAPK}$, slices were treated with IL-1Ra plus $A \beta$. Addition of IL-1Ra in the presence of $A \beta$ significantly reduced levels of phopho-p38 (7.6 $\pm 0.5 \mathrm{U} / \mathrm{ng} ; n=6$; $p<$ 0.05 vs $A \beta$ alone), suggesting the involvement of IL- $1 \beta$ in A $\beta$ mediated activation of $\mathrm{p} 38$ pathway.

Consistent with the aforementioned results showing that $\mathrm{p} 38$ MAPK activation is required for LTD, we found that the level of p38 MAPK phosphorylation (Fig. 6A) was significantly increased after LFS with respect to control condition without stimulation $(19.2 \pm 5.1 \mathrm{U} / \mathrm{ng}$ in vehicle plus LFS; $n=6 ; p<0.05$ vs vehicle 
without LFS). We observed a similar increase after LFS when RAGE signaling was blocked (19.8 $\pm 8 \mathrm{U} / \mathrm{ng}$ in anti-RAGE IgG-treated slices and $21.7 \pm 8 \mathrm{U} / \mathrm{ng}$ in DNMSR slices; $n=6$ in each group; $p<$ 0.05 vs vehicle without LFS). Interestingly, LFS-induced p38 MAPK activation was enhanced after 10 min of $1 \mu \mathrm{M} \mathrm{A} \beta$ perfusion with respect to vehicle-treated LFS stimulated slices $(42.5 \pm 11 \mathrm{U} / \mathrm{ng} ; n=$ $6 ; p<0.05$ vs vehicle, anti-RAGE IgG, and DNMSR after LFS stimulation). Similarly, RAGE blockade, deficiency of RAGE signaling in microglia, and treatment with IL-1Ra reduced significantly $\mathrm{A} \beta$-induced p38 MAPK activation after LFS (24.7 \pm 4 , $17.8 \pm 7.6,19.4 \pm 11.6 \mathrm{U} / \mathrm{ng} ; n=6$ each group; $p<0.05$ vs $A \beta$ plus LFS), even if a significant increase was still observed with respect to basal condition (vehicle-treated slices without LFS), which was consistent with a rescue of a normal LTD as shown in Figures $3 C-E$ and $4 D$.

Similarly, we measured JNK phosphorylation levels in EC slices after $\mathrm{A} \beta$ exposure and in the absence of LFS (Fig. $6 B)$. Slice perfusion with $1 \mu \mathrm{M} \mathrm{A} \beta$ for 10 min significantly increased the JNK phosphorylation compared with the vehicletreated slices $(141.9 \pm 25.3$ vs $73.8 \pm 2.9$ $\mathrm{U} / \mathrm{ng} ; n=6 ; p<0.05)$. As reported for p38 MAPK, A $\beta$ effect on JNK was completely prevented by RAGE blockade and deficiency of RAGE signaling in microglia $(94.5 \pm 10 \mathrm{U} / \mathrm{ng}$ in anti-RAGE IgG plus $\mathrm{A} \beta$ and $77.7 \pm 19 \mathrm{U} / \mathrm{ng}$ in DNMSR plus $\mathrm{A} \beta ; n=6 ; p<0.05$ vs $\mathrm{A} \beta$ alone) and IL-1Ra pretreatment $(93 \pm 8.7 \mathrm{U} / \mathrm{ng} ; n=$ 6 ; $p<0.05$ vs A $\beta$ alone). Since JNK activation is not required for LTD expression as shown in Figure 5B, JNK phosphorylation was not significantly increased in vehicle-treated slices after LFS (90.3 \pm 9.3 $\mathrm{U} / \mathrm{ng} ; n=6 ; p>0.05$ vs vehicle without LFS). Similar results (Fig. $6 B$ ) were obtained in slices pretreated with anti-RAGE IgG and in DNMSR slices after LFS $(67.8 \pm 13$ and $89.6 \pm 5.3 \mathrm{U} / \mathrm{ng}$, respectively; $n=6$ each group; $p>0.05$ vs vehicle). Thus, LFS per se did not change JNK phosphorylation. In contrast, in $A \beta$ treated slices, JNK was persistently activated even after LFS (175.9 $\pm 11.6 \mathrm{U} / \mathrm{ng}$; $n=6 ; p<0.05$ vs vehicle plus LFS), as an abnormal effect induced by $\mathrm{A} \beta(1-42)$. More importantly, JNK phosphorylation after $A \beta$ exposure and LFS was significantly reduced in anti-RAGE IgG-treated slices, DNMSR slices and IL1 Ra-treated slices with respect to slices exposed to $A \beta$ alone (Fig. $6 B)(94.5 \pm 10,105 \pm 13,94 \pm 9 \mathrm{U} / \mathrm{ng}$, respectively; $n=6$ each group; $p<0.05$ vs A $\beta$ plus LFS). Thus, levels measured by ELISA show that p38 MAPK and JNK are both hyperphosphorylated in slices exposed to $1 \mu \mathrm{M} \mathrm{A} \beta(1-42)$ under the control of microglial RAGE. We further examined JNK and p38 MAPK signaling
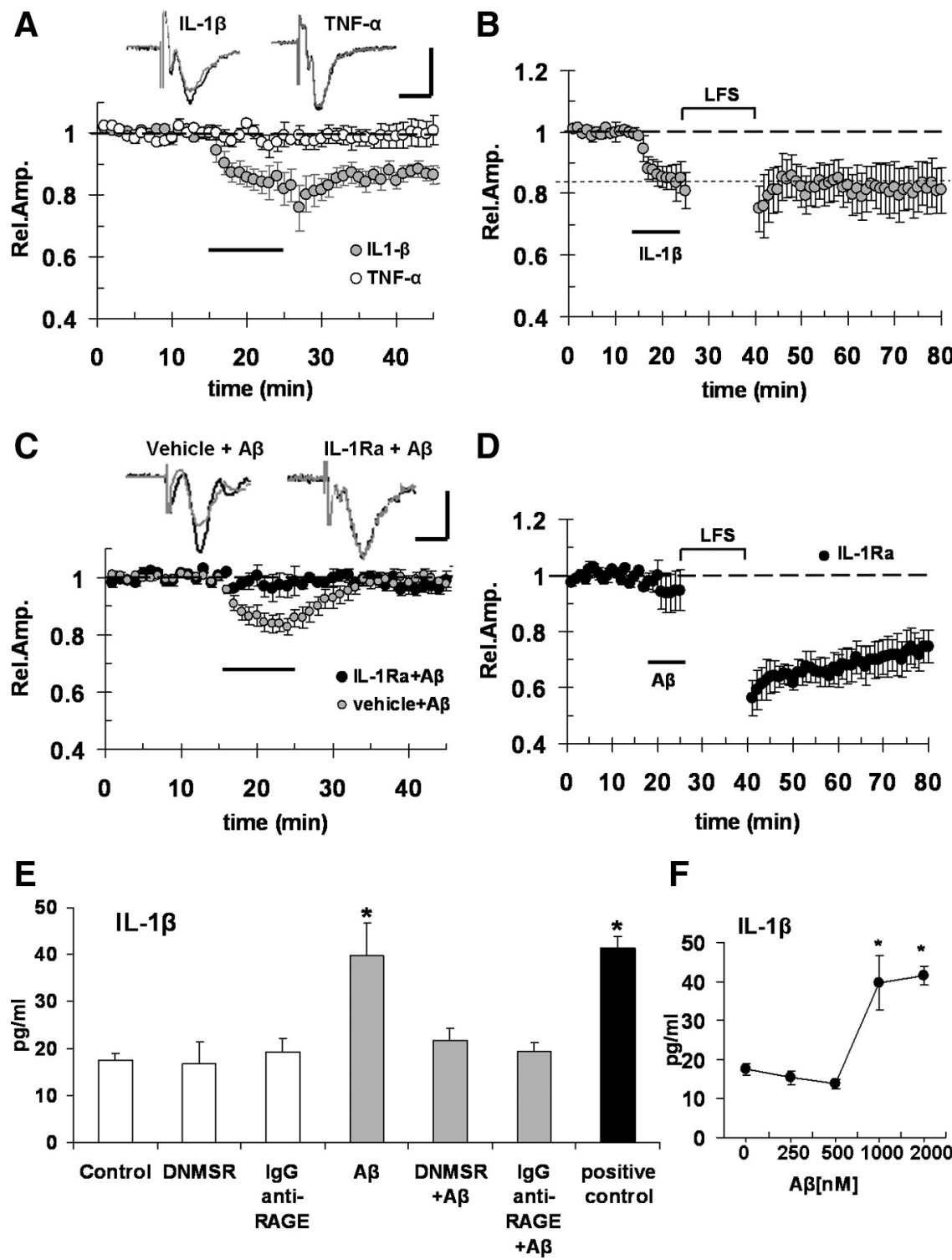

$\mathbf{F}$

Figure 4. $\quad A \beta$-induced depression and LTD impairment is partially mimicked by IL-1 $\beta$ and prevented by IL-1 $\beta$ receptor antagonist. $\boldsymbol{A}, \mathrm{IL}-1 \beta(1 \mathrm{ng} / \mathrm{ml}$; gray circles) treatment for $10 \mathrm{~min}$ (dark bar), but not TNF- $\alpha(5 \mathrm{ng} / \mathrm{ml}$; white circles), was able to significantly depress basal synaptic transmission. $\boldsymbol{B}, \mathrm{IL}-1 \beta(1 \mathrm{ng} / \mathrm{ml})$ perfusion for $10 \mathrm{~min}$ (dark bar) before LFS impaired LTD. $\boldsymbol{C}, \boldsymbol{D}$, When slices were treated with $20 \mathrm{ng} / \mathrm{ml}$ IL-1Ra, $1 \mu \mathrm{M} \mathrm{A} \beta$ (dark bar) failed to induce synaptic depression of FP amplitude (C, black circles) and prevented LTD impairment ( $\boldsymbol{D}$, black circles). The insets in $\boldsymbol{A}$ and $\boldsymbol{C}$ represent typical traces of FPs recordings before (dark line) and during (gray line) $A \beta$ perfusion. Calibration: horizontal, $5 \mathrm{~ms}$; vertical, $0.5 \mathrm{mV}$. E, The plot represents average IL-1 $\beta$ levels (in picograms per milliliter) in EC slices; IL-1 $\beta$ level was significantly increased in cortical slices exposed to $1 \mu \mathrm{m} \mathrm{A} \beta$ for $10 \mathrm{~min}$, whereas deficiency of RAGE signaling in microglia (DNMSR slices) or complete RAGE inactivation by anti-RAGE lgG $(2.5 \mu \mathrm{g} / \mathrm{ml})$ did not modify basal IL- $1 \beta$ levels but prevented $A \beta$ effect maintaining IL- $1 \beta$ levels comparable with control values ( $p<0.05$ vs control). Serum samples were used as positive control provided with the kit. $\boldsymbol{F}$, The plot represents IL-1 $\beta$ levels in EC slices exposed to increasing $A \beta$ concentrations; as reported in $E, 1 \mu \mathrm{m} \mathrm{A} \beta$ elevated IL-1 $\beta$ levels, whereas lower concentrations ( 250 and $500 \mathrm{~nm}$ ) of $A \beta$ did not produce any increase in IL- $1 \beta$ with respect to control slices; moreover, increase of $A \beta$ concentration up to $2 \mu \mathrm{m}$ did not induce significantly higher IL-1 $\beta$ levels with respect to those measured in $1 \mu \mathrm{m}$-treated slices ${ }^{*} p<0.05$ vs vehicle-treated slices (0), 250 and $500 \mathrm{~nm}$ ]. Error bars indicate SEM.

pathways by using specific inhibitors of their phosphorylation. Interestingly, the JNK inhibitor SP600125 significantly reduced p38 MAPK phosphorylation in $\mathrm{A} \beta$-exposed slices either before (Fig. $6 A)(4.6 \pm 1.5 \mathrm{U} / \mathrm{ng} ; p<0.05$ vs $\mathrm{A} \beta$ alone) or after LFS $(16.2 \pm 4.5 \mathrm{U} / \mathrm{ng} ; p<0.05$ vs $\mathrm{A} \beta$ plus LFS). In contrast, $\mathrm{p} 38$ MAPK inhibition with SB203580 was not able to prevent A $\beta$ induced activation of JNK (Fig. $6 B$ ). The most plausible interpretation of these results is that $A \beta /$ RAGE signaling induces an increase in JNK phosphorylation that controls p38 MAPK and 


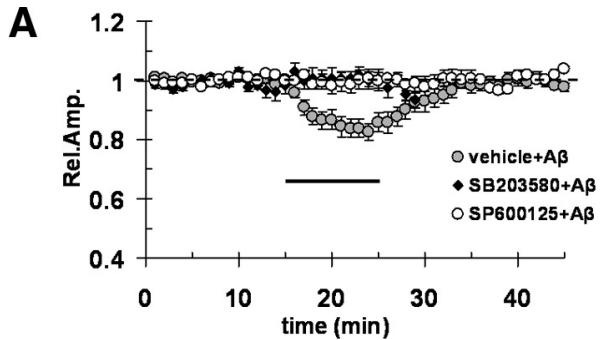

B
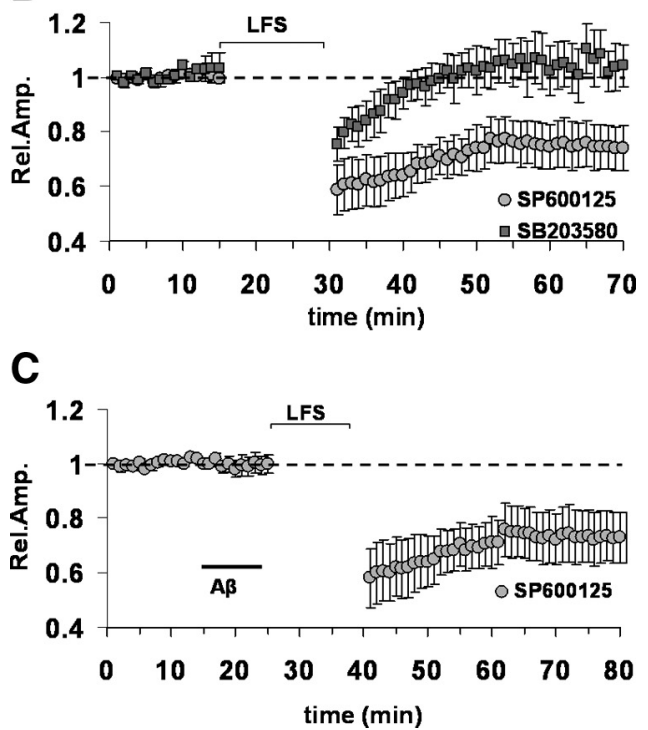

Figure 5. $A \beta$-induced depression and LTD impairment is prevented by inhibition of JNK and p38 MAPK. A, Treatment of slices with $1 \mu \mathrm{M}$ SB203580 and $20 \mu \mathrm{m}$ SP600125 (black diamond and white circles, respectively); application of $1 \mu \mathrm{m} \mathrm{A} \beta(1-42)$ for $10 \mathrm{~min}$ (dark bar) was unable to induce synaptic depression. $\boldsymbol{B}$, LFS-induced LTD was completely abolished by P38 MAPK inhibition with SB203580 (1 $\mu \mathrm{m}$; gray squares) but was normally expressed in slices after JNK inhibition with SP600125 (20 $\mu$ m; gray circles). C, SP600125 treatment rescued a normal LTD in slices after $1 \mu \mathrm{M} A \beta$ exposure (for $10 \mathrm{~min}$; dark bar). Error bars indicate SEM.

IL-1 $\beta$ levels. Indeed, ELISA revealed that blockade of JNK $(\mathrm{SP} 600125 ; 19.3 \pm 4.5 \mathrm{pg} / \mathrm{ml}$ in SP600125 plus A $\beta$ vs $39.7 \pm 6.9$ in $\mathrm{A} \beta$ alone; $p<0.05)$ but not $\mathrm{p} 38$ MAPK (SB203580; $38.8 \pm 5.3$ $\mathrm{pg} / \mathrm{ml}$ in SB203580 plus $\mathrm{A} \beta$ vs $39.7 \pm 6.9$ in $\mathrm{A} \beta$ alone; $p>0.05$ ) was able to significantly reduce IL- $1 \beta$ levels in slices exposed to $\mathrm{A} \beta$ (Fig. 6C).

\section{Discussion}

Oligomeric $\mathrm{A} \beta$ plays an important role in the development of neuronal impairment leading to cognitive deficits. Recent results showed that oligomeric soluble $\mathrm{A} \beta$ was able to induce an impairment of synaptic function in the hippocampus (for review, see Selkoe, 2002) and EC (Origlia et al., 2008), two vulnerable areas in AD (Braak and Braak, 1991) that play a crucial role in learning and memory (Witter et al., 1989; Braak et al., 1993; Suzuki and Amaral, 2004). In particular, human natural oligomers and synthetic oligomeric $\mathrm{A} \beta$ at low concentrations were capable of acutely inhibiting LTP (Lambert et al., 1998; Chen et al., 2002; Vitolo et al., 2002; Walsh et al., 2002, 2005; Wang et al., 2004; Zhao et al., 2004). Finally, several reports showed that administration of $\mathrm{A} \beta$ at higher concentrations than those inducing pure inhibitory effect on LTP (Origlia et al., 2008, 2009) depressed synaptic transmission and impaired a second form of long-term synaptic plasticity, namely the LTD, by increasing the synaptic removal of glutamate receptors (Snyder et al., 2005; Tyszkiewicz
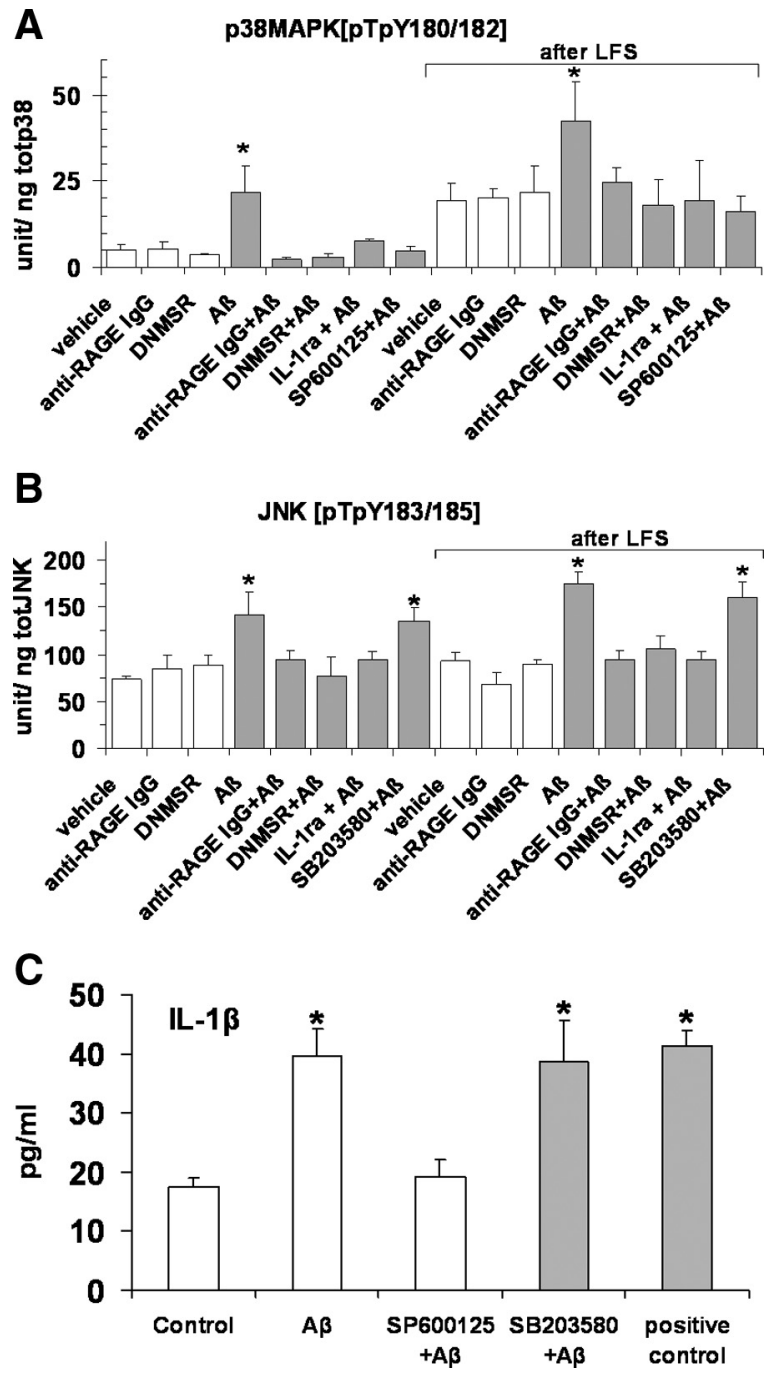

Figure 6. $A \beta(1 \mu \mathrm{M})$ increases $p 38 \mathrm{MAPK} / J \mathrm{NK}$ phosphorylation in cortical slices. $A$, The plot represents averaged phospho-p38 MAPK levels measured using ELISA and expressed as unit/ total content of $\mathrm{p} 38$ MAPK protein. Tissue levels of phospho-p38 MAPK after slices perfusion with $1 \mu \mathrm{M} A \beta(1-42)$ were significantly higher with respect to control vehicle-treated slices ( ${ }^{*} p<0.05$ vs control vehicle) both before and after LFS. Selective deficiency of RAGE signaling in microglia (DNMSR) and complete inactivation of RAGE with anti-RAGE IgG did not modify basal level of phospho-p38 MAPK ( $p>0.05$ vs control vehicle). Blockade of RAGE was able to prevent $A \beta$-induced increase of phospho-p38 MAPK ( $p<0.05$ vs slices treated with $A \beta$ alone), even if the increase induced by LFS was still present. p38 MAPK activation by $A \beta$ was also significantly reduced in slices treated with IL-1Ra ( $p<0.05$ vs $A \beta$ alone) and in slices treated with the JNK inhibitor SP600125 ( $p<0.05$ vs $A \beta$ alone). $\boldsymbol{B}$, The plot represents averaged phospho-JNK levels measured using ELISA and expressed as unit/total content of JNK protein. Elevated phospho-JNK levels were increased by $1 \mu \mathrm{m} A \beta$ treatment $\left({ }^{*} p<0.05\right.$ vs control vehicle) but not by LFS. Deficiency of RAGE signaling in microglia (DNMSR) and complete inactivation of RAGE with anti-RAGE IgG did not modify basal level of phospho-JNK both before and after LFS ( $p>0.05$ vs control vehicle). Blockade of RAGE was able to prevent $A \beta$-induced increase of phospho-JNK ( $p<0.05$ vs slices treated with $A \beta$ alone). Phospho-JNK level after 1 $\mu \mathrm{M} A \beta$ treatment was also significantly reduced in slices treated with IL-1 $\operatorname{Ra}(p<0.05$ vs $A \beta$ alone). $C$, The plot represents average IL-1 $\beta$ levels (in picograms per milliliter) in EC slices; IL-1 $\beta$ level was significantly increased in cortical slices exposed to $1 \mu \mathrm{mA} \beta$ for $10 \mathrm{~min}$, whereas inhibition of JNK (SP600125) but not of p38 MAPK (SB203580) prevented A $\beta$ effect and IL-1 $\beta$ levels were comparable with control values ( $p>0.05$ vs control). Error bars indicate SEM.

and Yan, 2005; Hsieh et al., 2006; Parameshwaran et al., 2007). Here, we demonstrated for the first time in the EC that a micromolar concentration of synthetic $\mathrm{A} \beta$ oligomers induces a depression of synaptic transmission and an impairment of NMDA-dependent form of LTD induced by LFS. We interpreted this result as sug- 
gesting that transient synaptic depression and disruption of LFSLTD by $\mathrm{A} \beta$ are governed by distinct synaptic mechanisms. Although we cannot completely rule out the possibility that previous synaptic depression interacts with LFS-LTD in the presence of $A \beta$ (when the two synaptic events are sequentially evoked as in our experimental conditions), we are confident that transient synaptic depression does not depend on LFS-LTD-related mechanism; indeed, we showed that previous induction of LFS-LTD does not occlude additional synaptic depression by A $\beta$.

Remarkably, $A \beta$ concurred to reduction of AMPA receptor function, according to previous studies supporting the involvement of this subtype of glutamate receptors on $A \beta$-dependent synaptic dysfunction (Hsieh et al., 2006; Parameshwaran et al., 2007). However, other reports showed that a second type of glutamate receptors, namely the NMDA receptor, is implicated in A $\beta$-dependent impairment of synaptic transmission (Kim et al., 2001; Snyder et al., 2005; Tyszkiewicz and Yan, 2005). A recent report in the hippocampus showed that oligomeric $\mathrm{A} \beta$ facilitates LTD induction interfering with NMDA and mGlu receptors $(\mathrm{Li}$ et al., 2009). Consistent with the report by Li et al. (2009) showing no significant change in the magnitude of NMDA receptordependent LTD after $A \beta$ treatment, in a previous paper from our laboratories (Origlia et al., 2008), we reported that synthetic $\mathrm{A} \beta(1-42)$ in the nanomolar range inhibits LTP leaving normal LTD. Thus, the present and previous reports suggest that oligomeric $\mathrm{A} \beta$ plays an important role in the progressive alteration of different synaptic functions and raise the important issue of identifying receptor(s) and signal transduction pathways responsible for neuronal impairment in AD.

We focused our study on RAGE-dependent signaling in neuronal and non-neuronal cells insulted by A $\beta$ (Yan et al., 1995; Hofmann et al., 1999; Lue et al., 2001; Schmidt et al., 2001; Deane et al., 2003; Lue et al., 2005). Previous reports showed that RAGE is implicated in disruption of synaptic function by oligomeric $A \beta$ (Arancio et al., 2004; Origlia et al., 2008). In particular, the finding that nanomolar oligomeric $\mathrm{A} \beta$ inhibits LTP through activation of RAGE in neurons (Origlia et al., 2008) prompted us to investigate whether cell-specific activation of RAGE by micromo$\operatorname{lar} \mathrm{A} \beta$ is involved in synaptic depression and LTD impairment. We provided evidence that blockade of RAGE signaling in microglial cells, but not in neurons, is capable of preventing $\mathrm{A} \beta$ dependent impairment of synaptic transmission and LTD inhibition. In addition, microglial RAGE plays a key role in the development of inflammatory response and cellular dysfunction in an A $\beta$ milieu (Du Yan et al., 1997; Lue et al., 2001; Fang et al., 2010). This raises the important issue of identifying factors and mechanisms released by microglial cells on exposition to $\mathrm{A} \beta$ that are capable of interacting with neurons. Activated microglial cells produce a wide spectrum of proinflammatory and cytotoxic factors, including TNF- $\alpha$ and IL-1 $\beta$ (for review, see Simm et al., 2004 ), two cytokines implicated in $\mathrm{AD}$ pathogenetic mechanisms (Akiyama et al., 2000). Importantly, IL-1 $\beta$ is implicated in disruption of synaptic efficacy induced by proinflammatory agents (Curran et al., 2003; Kelly et al., 2003). Moreover, in the hippocampus, IL-1 $\beta$ induced synaptic depression, inhibiting the subsequent induction of LTD in response to a $1 \mathrm{~Hz}$ electrical stimulation (Ikegaya et al., 2003). According to this, our data showed that IL- $1 \beta$, but not TNF- $\alpha$ is able to induce synaptic depression and LTD inhibition in EC, partially mimicking $\mathrm{A} \beta$ action. Notably, blocking IL- $1 \beta$ receptor by the addition of IL1 Ra completely abolished $\mathrm{A} \beta$ effect on synaptic transmission and prevented LTD impairment. Consistent with this observation, $\mathrm{A} \beta$, at micromolar but not at nanomolar concentrations, was able to increase IL-1 $\beta$ levels in EC slices. An important new finding was that functional inactivation of RAGE or deficiency of RAGE signaling in microglia significantly suppresses $A \beta$-induced IL- $1 \beta$ production. We propose that $A \beta /$ RAGE signaling in microglial cells leads to release of IL- $1 \beta$ that binds IL- $1 \beta$ receptor in neurons, causing synaptic depression and LTD impairment. Therefore, we consider IL- $1 \beta$ as a good candidate to link microglial RAGE activation to neuronal dysfunction in inflammatory process accompanying the accumulation of $\mathrm{A} \beta$ in $\mathrm{AD}$.

With regard to the intracellular signaling cascade $(\mathrm{s})$ activated by $\mathrm{A} \beta$-RAGE interaction, this/these include pathways such as p21ras, extracellular signal-regulated kinase 1/2 (p44/p42) MAPkinases, p38 MAPK, and SAPK (stress-activated protein kinase)/ JNK, Rho GTPases, phosphoinositol-3 kinase, and the JAK/STAT (signal transducer and activator of transcription) pathway. Activation of different protein kinase cascades is the principal target of RAGE activation in cell pathway controlling synaptic plasticity. In particular, we considered two different kinases, namely JNK and p38 MAPK, as potentially involved in synaptic dysfunction induced by oligomeric micromolar $A \beta$. Our recent report showed that nanomolar $\mathrm{A} \beta$ was able to phosphorylate $\mathrm{p} 38 \mathrm{MAPK}$ in cultured cortical neurons at concentrations and incubation time comparable with those used for LTP inhibition (Origlia et al., 2008; Takuma et al., 2009). In the present paper, we reported that p38 MAPK phosphorylation is required for LTD in EC, in agreement with previous reports (Bolshakov et al., 2000; Rush et al., 2002; Huang et al., 2004; Xiong et al., 2006). Furthermore, we showed that p38 MAPK phosphorylation is also required for LTD impairment. Notably, $\mathrm{A} \beta$ exposure increased phosphorylated levels of p38 MAPK, which were further enhanced after LFS, an electrical stimulation capable of phosphorylating p38 MAPK during LTD. Importantly, RAGE inactivation in microglia and blockade of IL- $1 \beta$ signaling prevented A $\beta$ induced p38 MAPK activation.

The other major stress-related kinase, JNK, was associated with IL- $1 \beta$-induced inhibition of LTP in hippocampus (Curran et al., 2003) and mGluR-dependent LTD as shown by using JNK1 knock-out mice (Li et al., 2007). In addition, bulk of results indicated that high $A \beta$ level is able to induce phosphorylation of JNK (Shoji et al., 2000; Morishima et al., 2001; Troy et al., 2001; Jang and Surh, 2002; Wei et al., 2002; Fogarty et al., 2003; Minogue et al., 2003). Differently to what demonstrated for p38 MAPK, JNK activation is not required for LTD in EC, since the specific inhibitor SP600125 did not affect this form of synaptic plasticity. However, abnormal JNK activation is an important step leading to $\mathrm{A} \beta$-induced synaptic depression and LTD impairment. Indeed, both synaptic depression and LTD impairment were prevented by SP600125. Remarkably, phosphorylated-JNK levels were increased in slices on micromolar $\mathrm{A} \beta$ exposure, an effect that was blocked by interfering with microglial RAGE and IL- $1 \beta$ signaling. Consistent with our data, a previous report showed that RAGE activation in neuronal and non-neuronal cells by different ligands was able to induce JNK phosphorylation (Chang et al., 2008; Bianchi et al., 2010). Finally, we showed that inhibition of JNK prevented $\mathrm{A} \beta$-dependent phosphorylation $\mathrm{p} 38$ MAPK and IL- $1 \beta$ increase, whereas the specific inhibition of p38 MAPK left JNK and IL- $1 \beta$ unaffected on exposure to $A \beta$. Together, our results suggest that $\mathrm{p} 38 \mathrm{MAPK}$ and JNK activation are important key events in $\mathrm{A} \beta$-mediated synaptic depression and LTD impairment. We interpreted our results as suggesting that micromolar oligomeric $\mathrm{A} \beta$ activates JNK by interacting with microglial RAGE. The kinase, in turn, controls the release of proinflamma- 
tory cytokines, such as IL- $1 \beta$, which may affect synaptic function through neuronal overactivation of p38 MAPK.

The present study also suggests that additional mechanisms may underlie synaptic dysfunction induced by $\mathrm{A} \beta$ behind LTP inhibition through activation of MAPK cascade (Wang et al., 2004; Origlia et al., 2008). We want to remark that, in animal models of $\mathrm{AD}$ characterized by progressive accumulation of $\mathrm{A} \beta$, LTP disruption occurs before deficits in basal synaptic transmission (Trinchese et al., 2004; Chang et al., 2006) and LTD (Chang et al., 2006). The nanomolar concentration of synthetic $A \beta(1-42)$ inhibits LTP through activation of RAGE in neurons and phosphorylation of p38 MAPK (Arancio et al., 2004; Origlia et al., 2008). However, increasing $A \beta$ concentration up to $1 \mu \mathrm{M}$ induces specific phosphorylation of p 38 MAPK and JNK in neuronal and non-neuronal cells that depend on microglial RAGE activation along with the induction of proinflammatory cytokine, such as IL- $1 \beta$. IL- $1 \beta$ would consequently affect basal synaptic transmission and LTD. Together, our previous and present results support the concept that impaired LTP characterizes an early stage in $\mathrm{AD}$ progression corresponding to a low $\mathrm{A} \beta$ load; later stages in $\mathrm{AD}$ progression are associated with a greater $\mathrm{A} \beta$ load that exaggerates impairments in basal synaptic transmission and LTD.

\section{References}

Akiyama H, Barger S, Barnum S, Bradt B, Bauer J, Cole GM, Cooper NR, Eikelenboom P, Emmerling M, Fiebich BL, Finch CE, Frautschy S, Griffin WS, Hampel H, Hull M, Landreth G, Lue L, Mrak R, Mackenzie IR, McGeer PL, et al. (2000) Inflammation and Alzheimer's disease. Neurobiol Aging 21:383-421.

Anderson WW, Collingridge GL (2001) The LTP program: a data acquisition program for on-line analysis of long-term potentiation and other synaptic events. J Neurosci Methods 108:71-83.

Arancio O, Zhang HP, Chen X, Lin C, Trinchese F, Puzzo D, Liu S, Hegde A, Yan SF, Stern A, Luddy JS, Lue LF, Walker DG, Roher A, Buttini M, Mucke L, Li W, Schmidt AM, Kindy M, Hyslop PA, et al. (2004) RAGE potentiates Abeta-induced perturbation of neuronal function in transgenic mice. EMBO J 23:4096-4105.

Bennett BL, Sasaki DT, Murray BW, O'Leary EC, Sakata ST, Xu W, Leisten JC, Motiwala A, Pierce S, Satoh Y, Bhagwat SS, Manning AM, Anderson DW (2001) SP600125, an anthrapyrazolone inhibitor of Jun N-terminal kinase. Proc Natl Acad Sci U S A 98:13681-13686.

Bianchi R, Giambanco I, Donato R (2010) S100B/RAGE-dependent activation of microglia via NF-kappaB and AP-1 Co-regulation of COX-2 expression by S100B, IL-1beta and TNF-alpha. Neurobiol Aging 31: 665-677.

Bolshakov VY, Carboni L, Cobb MH, Siegelbaum SA, Belardetti F (2000) Dual MAP kinase pathways mediate opposing forms of long-term plasticity at CA3-CA1 synapses. Nat Neurosci 3:1107-1112.

Braak H, Braak E (1991) Demonstration of amyloid deposits and neurofibrillary changes in whole brain sections. Brain Pathol 1:213-216.

Braak H, Braak E, Bohl J (1993) Staging of Alzheimer-related cortical destruction. Eur Neurol 33:403-408.

Chang EH, Savage MJ, Flood DG, Thomas JM, Levy RB, Mahadomrongkul V, Shirao T, Aoki C, Huerta PT (2006) AMPA receptor downscaling at the onset of Alzheimer's disease pathology in double knockin mice. Proc Natl Acad Sci U S A 103:3410-3415.

Chang JS, Wendt T, Qu W, Kong L, Zou YS, Schmidt AM, Yan SF (2008) Oxygen deprivation triggers upregulation of early growth response-1 by the receptor for advanced glycation end products. Circ Res 102:905-913.

Chapman PF, White GL, Jones MW, Cooper-Blacketer D, Marshall VJ, Irizarry M, Younkin L, Good MA, Bliss TV, Hyman BT, Younkin SG, Hsiao KK (1999) Impaired synaptic plasticity and learning in aged amyloid precursor protein transgenic mice. Nat Neurosci 2:271-276.

Chen QS, Wei WZ, Shimahara T, Xie CW (2002) Alzheimer amyloid betapeptide inhibits the late phase of long-term potentiation through calcineurin-dependent mechanisms in the hippocampal dentate gyrus. Neurobiol Learn Mem 77:354-371.

Chen X, Walker DG, Schmidt AM, Arancio O, Lue LF, Yan SD (2007)
RAGE: a potential target for Abeta-mediated cellular perturbation in Alzheimer's disease. Curr Mol Med 7:735-742.

Coogan AN, O'Neill LA, O'Connor JJ (1999) The p38 mitogen-activated protein kinase inhibitor SB203580 antagonizes the inhibitory effects of interleukin-1beta on long-term potentiation in the rat dentate gyrus in vitro. Neuroscience 93:57-69.

Curran BP, Murray HJ, O'Connor JJ (2003) A role for c-Jun N-terminal kinase in the inhibition of long-term potentiation by interleukin-1beta and long-term depression in the rat dentate gyrus in vitro. Neuroscience 118:347-357.

Deane R, Du Yan S, Submamaryan RK, LaRue B, Jovanovic S, Hogg E, Welch D, Manness L, Lin C, Yu J, Zhu H, Ghiso J, Frangione B, Stern A, Schmidt AM, Armstrong DL, Arnold B, Liliensiek B, Nawroth P, Hofman F, et al. (2003) RAGE mediates amyloid-beta peptide transport across the bloodbrain barrier and accumulation in brain. Nat Med 9:907-913.

Domenici L, Harding GW, Burkhalter A (1995) Patterns of synaptic activity in forward and feedback pathways within rat visual cortex. J Neurophysiol 74:2649-2664.

Du Yan S, Zhu H, Fu J, Yan SF, Roher A, Tourtellotte WW, Rajavashisth T, Chen X, Godman GC, Stern D, Schmidt AM (1997) Amyloid-beta peptide-receptor for advanced glycation endproduct interaction elicits neuronal expression of macrophage-colony stimulating factor: a proinflammatory pathway in Alzheimer disease. Proc Natl Acad Sci U S A 94:5296-5301.

Fang F, Lue LF, Yan S, Xu H, Luddy JS, Chen D, Walker DG, Stern DM, Yan S, Schmidt AM, Chen JX, Yan SS (2010) RAGE-dependent signaling in microglia contributes to neuroinflammation, $A \beta$ accumulation, and impaired learning/memory in a mouse model of Alzheimer's disease. FASEB J 24:1043-1055.

Fogarty MP, Downer EJ, Campbell V (2003) A role for c-Jun N-terminal kinase 1 (JNK1), but not JNK2, in the beta-amyloid-mediated stabilization of protein $\mathrm{p} 53$ and induction of the apoptotic cascade in cultured cortical neurons. Biochem J 371:789-798.

Hofmann MA, Drury S, Fu C, Qu W, Taguchi A, Lu Y, Avila C, Kambham N, Bierhaus A, Nawroth P, Neurath MF, Slattery T, Beach D, McClary J, Nagashima M, Morser J, Stern D, Schmidt AM (1999) RAGE mediates a novel proinflammatory axis: a central cell surface receptor for S100/calgranulin polypeptides. Cell 97:889-901.

Hsia AY, Masliah E, McConlogue L, Yu GQ, Tatsuno G, Hu K, Kholodenko D, Malenka RC, Nicoll RA, Mucke L (1999) Plaque-independent disruption of neural circuits in Alzheimer's disease mouse models. Proc Natl Acad Sci U S A 96:3228-3233.

Hsieh H, Boehm J, Sato C, Iwatsubo T, Tomita T, Sisodia S, Malinow R (2006) AMPAR removal underlies Abeta-induced synaptic depression and dendritic spine loss. Neuron 52:831-843.

Huang CC, Lee CC, Hsu KS (2004) An investigation into signal transduction mechanisms involved in insulin-induced long-term depression in the CA1 region of the hippocampus. J Neurochem 89:217-231.

Ikegaya Y, Delcroix I, Iwakura Y, Matsuki N, Nishiyama N (2003) Interleukin-1beta abrogates long-term depression of hippocampal CA1 synaptic transmission. Synapse 47:54-57.

Ingelsson M, Fukumoto H, Newell KL, Growdon JH, Hedley-Whyte ET, Frosch MP, Albert MS, Hyman BT, Irizarry MC (2004) Early Abeta accumulation and progressive synaptic loss, gliosis, and tangle formation in AD brain. Neurology 62:925-931.

Jang JH, Surh YJ (2002) beta-Amyloid induces oxidative DNA damage and cell death through activation of c-Jun N-terminal kinase. Ann N Y Acad Sci 973:228-236.

Kelly A, Vereker E, Nolan Y, Brady M, Barry C, Loscher CE, Mills KH, Lynch MA (2003) Activation of p38 plays a pivotal role in the inhibitory effect of lipopolysaccharide and interleukin-1 beta on long term potentiation in rat dentate gyrus. J Biol Chem 278:19453-19462.

Kim JH, Anwyl R, Suh YH, Djamgoz MB, Rowan MJ (2001) Use-dependent effects of amyloidogenic fragments of $\beta$-amyloid precursor protein on synaptic plasticity in rat hippocampus in vivo. J Neurosci 21:1327-1333.

Kourrich S, Chapman CA (2003) NMDA receptor-dependent long-term synaptic depression in the entorhinal cortex in vitro. J Neurophysiol 89:2112-2119.

Lali FV, Hunt AE, Turner SJ, Foxwell BM (2000) The pyridinyl imidazole inhibitor SB203580 blocks phosphoinositide-dependent protein kinase activity, protein kinase B phosphorylation, and retinoblastoma hyper- 
phosphorylation in interleukin-2-stimulated T cells independently of p38 mitogen-activated protein kinase. J Biol Chem 275:7395-7402.

Lambert MP, Barlow AK, Chromy BA, Edwards C, Freed R, Liosatos M, Morgan TE, Rozovsky I, Trommer B, Viola KL, Wals P, Zhang C, Finch CE, Krafft GA, Klein WL (1998) Diffusible, nonfibrillar ligands derived from Abeta 1-42 are potent central nervous system neurotoxins. Proc Natl Acad Sci U S A 95:6448-6453.

Li QX, Maynard C, Cappai R, McLean CA, Cherny RA, Lynch T, Culvenor JG, Trevaskis J, Tanner JE, Bailey KA, Czech C, Bush AI, Beyreuther K, Masters CL (1999) Intracellular accumulation of detergent-soluble amyloidogenic A beta fragment of Alzheimer's disease precursor protein in the hippocampus of aged transgenic mice. J Neurochem 72:2479-2487.

Li S, Hong S, Shepardson NE, Walsh DM, Shankar GM, Selkoe D (2009) Soluble oligomers of amyloid beta protein facilitate hippocampal longterm depression by disrupting neuronal glutamate uptake. Neuron 62:788-801.

Li XM, Li CC, Yu SS, Chen JT, Sabapathy K, Ruan DY (2007) JNK1 contributes to metabotropic glutamate receptor-dependent long-term depression and short-term synaptic plasticity in the mice area hippocampal CA1. Eur J Neurosci 25:391-396.

Lue LF, Walker DG, Brachova L, Beach TG, Rogers J, Schmidt AM, Stern DM, Yan SD (2001) Involvement of microglial receptor for advanced glycation endproducts (RAGE) in Alzheimer's disease: identification of a cellular activation mechanism. Exp Neurol 171:29-45.

Lue LF, Yan SD, Stern DM, Walker DG (2005) Preventing activation of receptor for advanced glycation endproducts in Alzheimer's disease. Curr Drug Targets CNS Neurol Disord 4:249-266.

Lustbader JW, Cirilli M, Lin C, Xu HW, Takuma K, Wang N, Caspersen C, Chen X, Pollak S, Chaney M, Trinchese F, Liu S, Gunn-Moore F, Lue LF, Walker DG, Kuppusamy P, Zewier ZL, Arancio O, Stern D, Yan SS, et al. (2004) ABAD directly links Abeta to mitochondrial toxicity in Alzheimer's disease. Science 304:448-452.

Minogue AM, Schmid AW, Fogarty MP, Moore AC, Campbell VA, Herron CE, Lynch MA (2003) Activation of the c-Jun N-terminal kinase signaling cascade mediates the effect of amyloid-beta on long term potentiation and cell death in hippocampus: a role for interleukin-1beta? J Biol Chem 278:27971-27980.

Morishima Y, Gotoh Y, Zieg J, Barrett T, Takano H, Flavell R, Davis RJ, Shirasaki Y, Greenberg ME (2001) $\beta$-Amyloid induces neuronal apoptosis via a mechanism that involves the c-Jun $\mathrm{N}$-terminal kinase pathway and the induction of Fas ligand. J Neurosci 21:7551-7560.

Mucke L, Masliah E, Yu GQ, Mallory M, Rockenstein EM, Tatsuno G, Hu K, Kholodenko D, Johnson-Wood K, McConlogue L (2000) High-level neuronal expression of $\mathrm{A} \beta$ 1-42 in wild-type human amyloid protein precursor transgenic mice: synaptotoxicity without plaque formation. J Neurosci 20:4050-4058.

Oddo S, Caccamo A, Shepherd JD, Murphy MP, Golde TE, Kayed R, Metherate R, Mattson MP, Akbari Y, LaFerla FM (2003) Triple-transgenic model of Alzheimer's disease with plaques and tangles: intracellular Abeta and synaptic dysfunction. Neuron 39:409-421.

Origlia N, Righi M, Capsoni S, Cattaneo A, Fang F, Stern DM, Chen JX, Schmidt AM, Arancio O, Yan SD, Domenici L (2008) Receptor for advanced glycation end product-dependent activation of p38 mitogenactivated protein kinase contributes to amyloid- $\beta$-mediated cortical synaptic dysfunction. J Neurosci 28:3521-3530.

Origlia N, Capsoni S, Cattaneo A, Fang F, Arancio O, Yan SD, Domenici L (2009) Abeta-dependent Inhibition of LTP in different intracortical circuits of the visual cortex: the role of RAGE. J Alzheimers Dis 17:59-68.

Parameshwaran K, Sims C, Kanju P, Vaithianathan T, Shonesy BC, Dhanasekaran M, Bahr BA, Suppiramaniam V (2007) Amyloid beta-peptide Abeta(1-42) but not Abeta(1-40) attenuates synaptic AMPA receptor function. Synapse 61:367-374.

Pei JJ, Braak E, Braak H, Grundke-Iqbal I, Iqbal K, Winblad B, Cowburn RF (2001) Localization of active forms of c-Jun kinase (JNK) and p38 kinase in Alzheimer's disease brains at different stages of neurofibrillary degeneration. J Alzheimers Dis 3:41-48.

Pesavento E, Capsoni S, Domenici L, Cattaneo A (2002) Acute cholinergic rescue of synaptic plasticity in the neurodegenerating cortex of antinerve-growth-factor mice. Eur J Neurosci 15:1030-1036.

Pickering M, Cumiskey D, O'Connor JJ (2005) Actions of TNF-alpha on glutamatergic synaptic transmission in the central nervous system. Exp Physiol 90:663-670.
Raymond CR, Ireland DR, Abraham WC (2003) NMDA receptor regulation by amyloid-beta does not account for its inhibition of LTP in rat hippocampus. Brain Res 968:263-272.

Rush AM, Wu J, Rowan MJ, Anwyl R (2002) Group I metabotropic glutamate receptor (mGluR)-dependent long-term depression mediated via p38 mitogen-activated protein kinase is inhibited by previous highfrequency stimulation and activation of mGluRs and protein kinase $\mathrm{C}$ in the rat dentate gyrus in vitro. J Neurosci 22:6121-6128.

Sakaguchi T, Yan SF, Yan SD, Belov D, Rong LL, Sousa M, Andrassy M, Marso SP, Duda S, Arnold B, Liliensiek B, Nawroth PP, Stern DM, Schmidt AM, Naka Y (2003) Central role of RAGE-dependent neointimal expansion in arterial restenosis. J Clin Invest 111:959-972.

Sasahara M, Fries JW, Raines EW, Gown AM, Westrum LE, Frosch MP, Bonthron DT, Ross R, Collins T (1991) PDGF B-chain in neurons of the central nervous system, posterior pituitary, and in a transgenic model. Cell 64:217-227.

Schmidt AM, Yan SD, Yan SF, Stern DM (2001) The multiligand receptor RAGE as a progression factor amplifying immune and inflammatory responses. J Clin Invest 108:949-955.

Selkoe DJ (2002) Alzheimer's disease is a synaptic failure. Science 298:789-791.

Shankar GM, Li S, Mehta TH, Garcia-Munoz A, Shepardson NE, Smith I, Brett FM, Farrell MA, Rowan MJ, Lemere CA, Regan CM, Walsh DM, Sabatini BL, Selkoe DJ (2008) Amyloid-beta protein dimers isolated directly from Alzheimer's brains impair synaptic plasticity and memory. Nat Med 14:837-842.

Shemer I, Holmgren C, Min R, Fülöp L, Zilberter M, Sousa KM, Farkas T, Härtig W, Penke B, Burnashev N, Tanila H, Zilberter Y, Harkany T (2006) Non-fibrillar beta-amyloid abates spike-timing-dependent synaptic potentiation at excitatory synapses in layer $2 / 3$ of the neocortex by targeting postsynaptic AMPA receptors. Eur J Neurosci 23:2035-2047.

Shoji M, Iwakami N, Takeuchi S, Waragai M, Suzuki M, Kanazawa I, Lippa CF, Ono S, Okazawa H (2000) JNK activation is associated with intracellular beta-amyloid accumulation. Brain Res Mol Brain Res 85:221-233.

Simm A, Casselmann C, Schubert A, Hofmann S, Reimann A, Silber RE (2004) Age associated changes of AGE-receptor expression: RAGE upregulation is associated with human heart dysfunction. Exp Gerontol 39:407-413.

Simmons LK, May PC, Tomaselli KJ, Rydel RE, Fuson KS, Brigham EF, Wright S, Lieberburg I, Becker GW, Brems DN, Li WY (1994) Secondary structure of amyloid beta-peptide correlates with neurotoxic activity in vitro. Mol Pharmacol 45:373-379.

Snyder EM, Nong Y, Almeida CG, Paul S, Moran T, Choi EY, Nairn AC, Salter MW, Lombroso PJ, Gouras GK, Greengard P (2005) Regulation of NMDA receptor trafficking by amyloid-beta. Nat Neurosci 8:1051-1058.

Suzuki WA, Amaral DG (2004) Functional neuroanatomy of the medial temporal lobe memory system. Cortex 40:220-222.

Takuma K, Yao J, Huang J, Xu H, Chen X, Luddy J, Trillat AC, Stern DM, Arancio O, Yan SS (2005) ABAD enhances Abeta-induced cell stress via mitochondrial dysfunction. FASEB J 19:597-598.

Takuma K, Fang F, Zhang W, Yan S, Fukuzaki E, Du H, Sosunov A, McKhann G, Funatsu Y, Nakamichi N, Nagai T, Mizoguchi H, Ibi D, Hori O, Ogawa S, Stern DM, Yamada K, Yan SS (2009) RAGE-mediated signaling contributes to intraneuronal transport of amyloid-beta and neuronal dysfunction. Proc Natl Acad Sci U S A 106:20021-20026.

Trinchese F, Liu S, Battaglia F, Walter S, Mathews PM, Arancio O (2004) Progressive age-related development of Alzheimer-like pathology in APP/ PS1 mice. Ann Neurol 55:801-814.

Troy CM, Rabacchi SA, Xu Z, Maroney AC, Connors TJ, Shelanski ML, Greene LA (2001) beta-Amyloid-induced neuronal apoptosis requires c-Jun N-terminal kinase activation. J Neurochem 77:157-164.

Tyszkiewicz JP, Yan Z (2005) beta-Amyloid peptides impair PKCdependent functions of metabotropic glutamate receptors in prefrontal cortical neurons. J Neurophysiol 93:3102-3111.

Vitolo OV, Sant'Angelo A, Costanzo V, Battaglia F, Arancio O, Shelanski M (2002) Amyloid beta-peptide inhibition of the PKA/CREB pathway and long-term potentiation: reversibility by drugs that enhance cAMP signaling. Proc Natl Acad Sci U S A 99:13217-13221.

Walsh DM, Klyubin I, Fadeeva JV, Cullen WK, Anwyl R, Wolfe MS, Rowan MJ, Selkoe DJ (2002) Naturally secreted oligomers of amyloid beta protein potently inhibit hippocampal long-term potentiation in vivo. Nature 416:535-539. 
Walsh DM, Townsend M, Podlisny MB, Shankar GM, Fadeeva JV, El Agnaf O, Hartley DM, Selkoe DJ (2005) Certain inhibitors of synthetic amyloid $\beta$-peptide $(\mathrm{A} \beta$ ) fibrillogenesis block oligomerization of natural $\mathrm{A} \beta$ and thereby rescue long-term potentiation. J Neurosci 25:2455-2462.

Wang HW, Pasternak JF, Kuo H, Ristic H, Lambert MP, Chromy B, Viola KL, Klein WL, Stine WB, Krafft GA, Trommer BL (2002) Soluble oligomers of beta amyloid (1-42) inhibit long-term potentiation but not long-term depression in rat dentate gyrus. Brain Res 924:133-140.

Wang Q, Walsh DM, Rowan MJ, Selkoe DJ, Anwyl R (2004) Block of longterm potentiation by naturally secreted and synthetic amyloid $\beta$-peptide in hippocampal slices is mediated via activation of the kinases c-Jun $\mathrm{N}$-terminal kinase, cyclin-dependent kinase 5 , and p38 mitogen-activated protein kinase as well as metabotropic glutamate receptor type 5 . J Neurosci 24:3370-3378.

Wei W, Norton DD, Wang X, Kusiak JW (2002) A $\beta$ 17-42 in Alzheimer's disease activates JNK and caspase- 8 leading to neuronal apoptosis. Brain 125:2036-2043

Wendt TM, Tanji N, Guo J, Kislinger TR, Qu W, Lu Y, Bucciarelli LG, Rong LL, Moser B, Markowitz GS, Stein G, Bierhaus A, Liliensiek B, Arnold B, Nawroth PP, Stern DM, D'Agati VD, Schmidt AM (2003) RAGE drives the development of glomerulosclerosis and implicates podocyte activation in the pathogenesis of diabetic nephropathy. Am J Pathol 162: $1123-1137$.

Witter MP, Groenewegen HJ, Lopes da Silva FH, Lohman AH (1989) Func- tional organization of the extrinsic and intrinsic circuitry of the parahippocampal region. Prog Neurobiol 33:161-253.

Xiong W, Kojic LZ, Zhang L, Prasad SS, Douglas R, Wang Y, Cynader MS (2006) Anisomycin activates p38 MAP kinase to induce LTD in mouse primary visual cortex. Brain Res 1085:68-76.

Yan SD, Yan SF, Chen X, Fu J, Chen M, Kuppusamy P, Smith MA, Perry G, Godman GC, Nawroth P, Zweier JL, Stern D (1995) Non-enzymatically glycated tau in Alzheimer's disease induces neuronal oxidant stress resulting in cytokine gene expression and release of amyloid beta-peptide. Nat Med 1:693-699.

Yan SD, Chen X, Fu J, Chen M, Zhu H, Roher A, Slattery T, Zhao L, Nagashima M, Morser J, Migheli A, Nawroth P, Stern D, Schmidt AM (1996) RAGE and amyloid-beta peptide neurotoxicity in Alzheimer's disease. Nature 382:685-691.

Yan Y, Liu Y, Sorci M, Belfort G, Lustbader JW, Yan SS, Wang C (2007) Surface plasmon resonance and nuclear magnetic resonance studies of ABAD-Abeta interaction. Biochemistry 46:1724-1731.

Zhao D, Watson JB, Xie CW (2004) Amyloid beta prevents activation of calcium/calmodulin-dependent protein kinase II and AMPA receptor phosphorylation during hippocampal long-term potentiation. J Neurophysiol 92:2853-2858.

Zhu JJ, Qin Y, Zhao M, Van Aelst L, Malinow R (2002) Ras and Rap control AMPA receptor trafficking during synaptic plasticity. Cell 110:443-455.

Zhu X, Mei M, Lee HG, Wang Y, Han J, Perry G, Smith MA (2005) p38 activation mediates amyloid-beta cytotoxicity. Neurochem Res 30:791-796. 